\section{ENVIRONMENTAL} RESTORATION PROGRAM

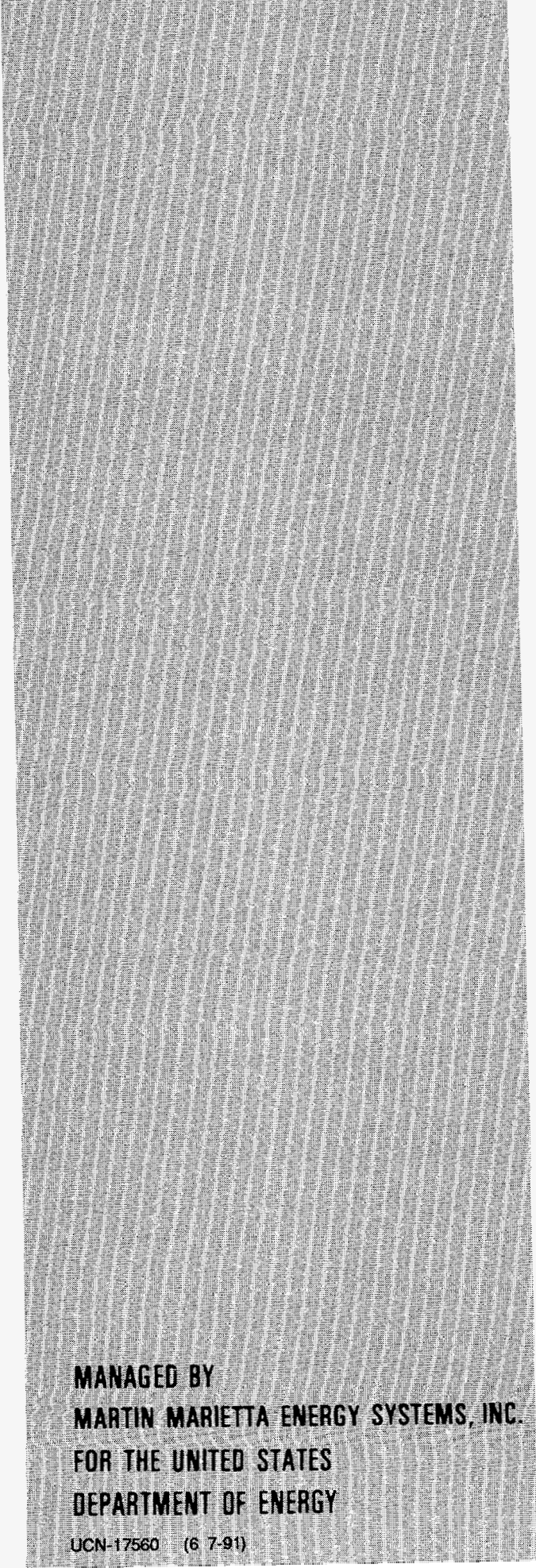

\section{Survey of Protected Terrestrial Vertebrates on the Oak Ridge Reservation}

\section{Annual Progress Report}


This report has been reproduced directly from the best available copy.

Available to DOE and DOE contractors from the Office of Scientific and Technical Information, P.O. Box 62, Oak Ridge, TN 37831; prices available from 615-576-8401 (fax 615-576-2865).

Available to the public from the National Technical Information Service, U.S. Department of Commerce, 5285 Port Royal Rd., Springfield, VA 22161.

\section{DISCLAIMER}

This report was prepared as an account of work sponsored by an agency of the United States Government. Neither the United States Government nor any agency thereof, nor any of their employees, makes any warranty, express or implied, or assumes any legal liability or responsibility for the accuracy, completeness, or usefulness of any information, apparatus, product, or process disclosed, or represents that its use would not infringe privately owned rights. Reference herein to any specific commercial product, process, or service by trade name, trademark, manufacturer, or otherwise does not necessarily constitute or imply its endorsement, recommendation, or favoring by the United States Government or any agency thereof. The views and opinions of authors expressed herein do not necessarily state or reflect those of the United States Government or any agency thereof. 


\section{DISCLAMMER}

Portions of this document may be illegible in electronic image products. Images are produced from the best available original document. 


\title{
Survey of Protected Terrestrial Vertebrates on the Oak Ridge Reservation 1995 Annual Progress Report
}

\author{
E. R. Vail \\ J. M. Mitchell \\ J.W. Webb \\ A. L. King \\ P. A. Hamlett
}

Date Issued-November 1995

\author{
Prepared by \\ Environmental Restoration Division \\ Environmental Science Division \\ Computational Physics and Engineering \\ P.O. Box 2003
}

Oak Ridge, Tennessee 37831-7298

\section{Prepared for the}

U.S. Department of Energy

Office of Environmental Management

under budget and reporting code EW 20

\section{LOCKHEED MARTIN ENERGY SYSTEMS, INC. \\ managing the \\ Environmental Management Activities at}

Oak Ridge K-25 Site Paducah Gaseous Diffusion Plant

Oak Ridge Y-12 Plant Portsmouth Gaseous Diffusion Plant

Oak Ridge National Laboratory

under contract DE-AC05-84OR21400

for the

U.S. DEPARTMENT OF ENERGY

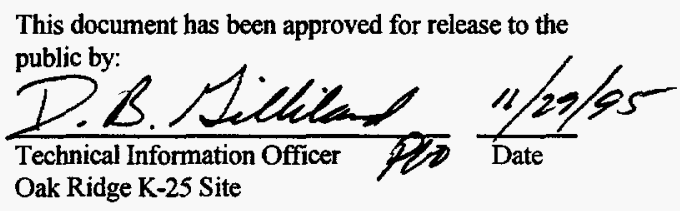




\section{Author and Contributor Affiliations}

Elizabeth R. Vail and Jason $M$. Mitchell are subcontractors with Jaycor Corporation. J. Warren Webb, Project Manager, is a member of the Environmental Sciences Division, Oak Ridge National Laboratory. Amy L. King, Program Manager, is a member of Computational Physics and Engineering, Oak Ridge National Laboratory. Patricia A. Hamlett is a subcontractor with the University of Tennessee. 


\section{PREFACE}

This technical report discussing surveys of threatened and endangered terrestrial vertebrates on the Oak Ridge Reservation was prepared as an annual progress report. This work was performed under Work Breakdown Structure 1.4.12.2.3.04.06 (Activity Sheet 8304) and Milestone Number 8304-03-01, "Issue Progress Report on Environmentally Sensitive Areas Surveys." 


\section{CONTENTS}

FIGURES $\ldots \ldots \ldots \ldots \ldots \ldots \ldots \ldots \ldots \ldots \ldots \ldots \ldots \ldots \ldots \ldots \ldots$ vii

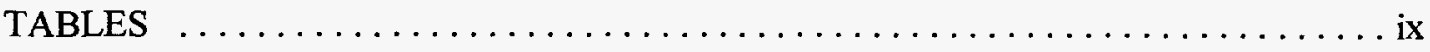

EXECUTIVE SUMMARY $\ldots \ldots \ldots \ldots \ldots \ldots \ldots \ldots \ldots \ldots \ldots \ldots \ldots \ldots \ldots \ldots \ldots \ldots$

1. INTRODUCTION $\ldots \ldots \ldots \ldots \ldots \ldots \ldots \ldots \ldots \ldots \ldots \ldots \ldots \ldots \ldots \ldots \ldots \ldots$

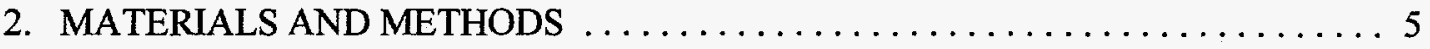

2.1 SELECTION OF SURVEY SITES $\ldots \ldots \ldots \ldots \ldots \ldots \ldots \ldots \ldots \ldots \ldots \ldots \ldots$

2.2 TRAPPING AND SURVEY METHODS $\ldots \ldots \ldots \ldots \ldots \ldots \ldots \ldots \ldots \ldots$

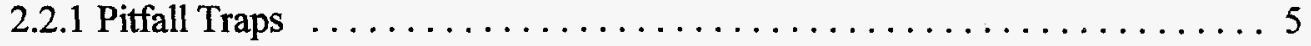

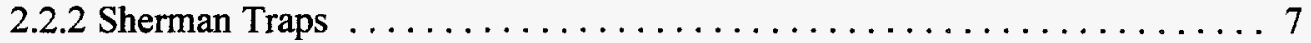

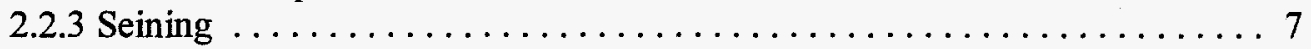

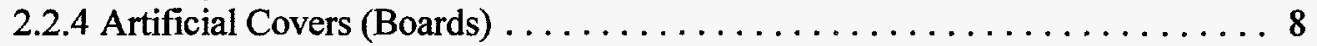

2.2 .5 Cave Entry . . . . . . . . . . . .

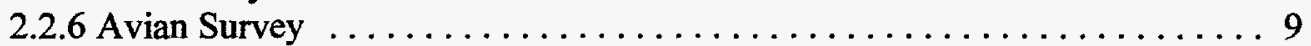

2.3 HABITAT ANALYSIS $\ldots \ldots \ldots \ldots \ldots \ldots \ldots \ldots \ldots \ldots \ldots \ldots \ldots \ldots$

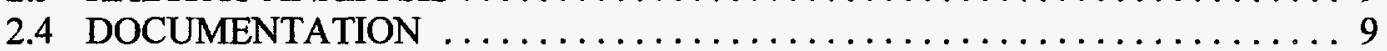

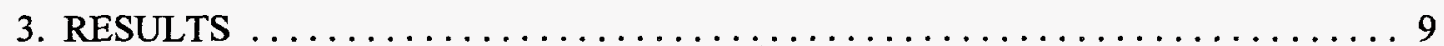

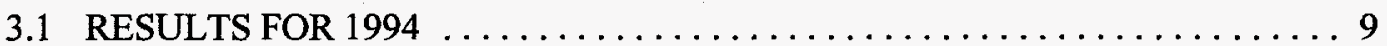

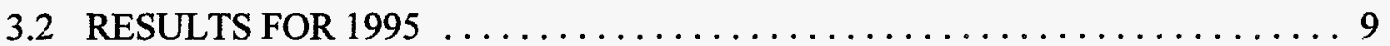

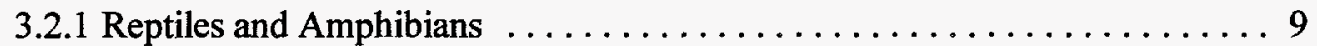

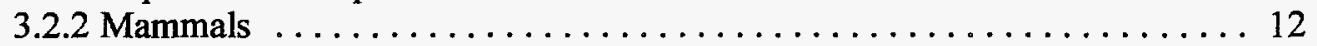

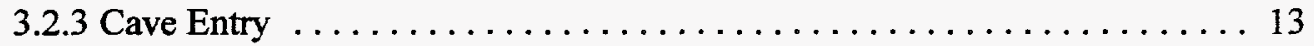

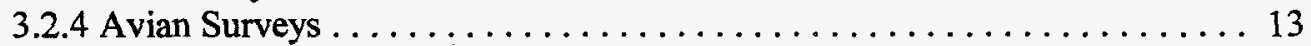

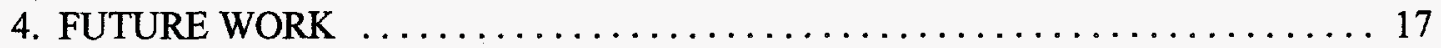

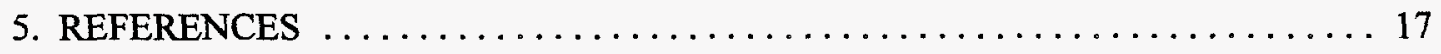

Appendices:

A. TWRA 1994A AND TWRA 1994B: SPECIES LISTED AS

THREATENED, ENDANGERED, OR IN NEED OF MANAGEMENT

B. TWENTY-NINE NONTARGETED SPECIES

C. NONAVIAN SITE LOCATIONS ON THE ORR

D. SITE MAPS FOR PITFALL AND SHERMAN TRAP PLACEMENT ON THE ORR, FEBRUARY-SEPTEMBER 1995

E. CAVE LOCATIONS ON THE ORR

F. MAPS OF SURVEYED CAVES ON THE ORR, FEBRUARY-SEPTEMBER 1995

G. PROTOCOL FOR HABITAT SAMPLING

H. DATA SHEETS USED FOR 1995

I. LISTED SPECIES OBSERVED ON THE ORR DURING 1994

J. SPECIES OBSERVED ON THE ORR DURING 1994 BUT SUBSEQUENTLY DELISTED

K. INDIVIDUALS WHO HAVE IDENTIFIED T\&E BIRD SPECIES ON THE ORR 



\section{FIGURES}

1 Sampling compartments for reptiles, amphibians, and mammals on the ORR $\ldots \ldots .5$

2 Pitfall and Sherman trap grid placement . . . . . . . . . . . . . . . . . 6

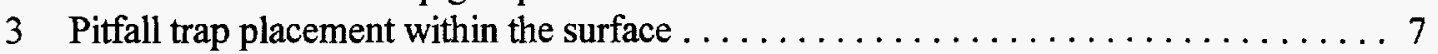

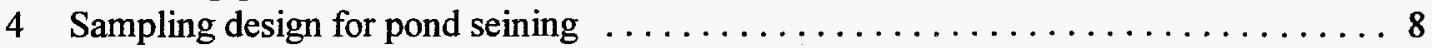





\section{TABLES}

1 Reptile and amphibian species which have a range that extends into the ORR ..... 2

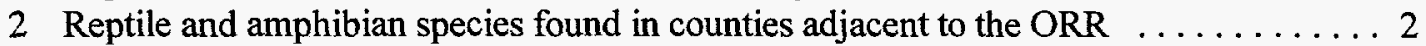

3 Reptile and amphibian species which have been found in eastern Tennessee

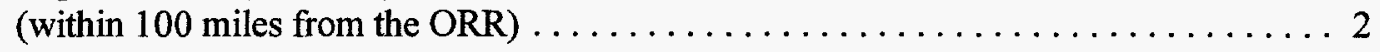

4 Mammal species which have been historically found on the ORR .......... 3

5 Mammal species which have been found in counties adjacent to the ORR ....... 3

6 Mammal species which have been found in eastern Tennessee (within 100 miles of the ORR) $\ldots \ldots \ldots \ldots \ldots \ldots \ldots \ldots \ldots$

7 Selected bird species most likely to be found on the ORR $\ldots \ldots \ldots \ldots \ldots \ldots \ldots$

8 Bird species for which adequate habitat exist on ORR but are uncommon in eastern Tennessee $\ldots \ldots \ldots \ldots \ldots \ldots \ldots \ldots \ldots \ldots$

9 Reptiles and amphibians observed/collected on the ORR from October 1994 through September $1995 \ldots \ldots \ldots \ldots \ldots \ldots \ldots \ldots \ldots \ldots$

10 Southeastern shrew (Sorex longirostris) captured in pitfall traps on the ORR from February through September 1995 by collection site $\ldots \ldots \ldots \ldots 12$

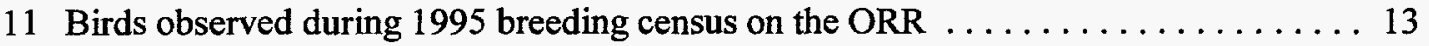





\section{EXECUTIVE SUMMARY}

This progress report discusses surveys of protected terrestrial vertebrates on the Oak Ridge Reservation (ORR) from October 1994 through September 1995. These surveys are important to help avoid or minimize potential impacts of projects on the ORR to species listed as threatened, endangered, or in need of management by the U.S. Fish and Wildlife Service and the Tennessee Wildlife Resources Agency.

Currently, there are 69 species of federally or state-listed terrestrial vertebrates ( 20 reptiles and amphibians, 20 mammals, and 29 birds) that may occur in Tennessee. Not all of these are expected to occur on the ORR, nor do resources permit comprehensive sampling for all of them over the entire ORR. To effectively organize sampling efforts, listed animal species that might be present were targeted using a prioritization system based on historical and recent sightings, species distributions, literature reviews, and personal communications.

Sampling was conducted during the time of the year when each targeted species would most likely be encountered. Several trapping and surveying methods were used, including pitfall traps, Sherman traps, seining, artificial covers, and cave and avian surveys.

Thirty-seven species of reptiles and amphibians were observed or collected from October 1994 through September 1995. The coal skink was the only listed species provisionally found (i.e., independent verification was not available). Particular effort was made to find the listed mole salamander, but none were located.

Fifteen species of mammals were trapped during the reporting year. Of the 13 threatened, endangered, or in-need-of-management species targeted, 2 were located: the federally endangered gray bat ( 1 verified and 1 unverified sighting) and the state in need of management southeastern shrew (13 trapped).

Fourteen species of listed birds were sighted from October 1994 through September 1995. Multiple sightings were recorded for all species except for the anhinga, the sandhill crane, and the peregrine falcon (one sighting each). The species sighted that are listed as in need of management are sharp-shinned hawk, Cooper's hawk, grasshopper sparrow, anhinga, great egret, northern harrier, olive-sided flycatcher, little blue heron, sandhill crane, double-crested cormorant, and yellow-bellied sapsucker. The species sighted that are federally listed as threatened are the peregrine falcon and bald eagle. The osprey is the only species sighted that is listed as threatened by the state.

Research on this project will continue from October 1995 through May 1996. Sampling plans and other work for this period include surveys for the jumping mouse, southeastern shrew, and Tennessee cave salamander. Habitat analysis will be conducted at all previous and new sampling sites. Active searches will continue at various locations for reptiles and amphibians. Bird surveys will continue with winter point counts, monitoring of the fall and spring migrations, and a bald eagle count. A final report will be prepared at the conclusion of the research. 


\section{INTRODUCTION}

Animal species in Tennessee are protected by both federal and state laws. The federal Endangered Species Act confers protection on species listed as either threatened or endangered; federal agencies may not undertake actions which might harm these species without assessing the impacts of the action on the listed species, and under appropriate circumstances consulting with the U.S. Fish and Wildlife Service. It is also advisable for federal agencies to consider species which are proposed for federal listing or which are candidates for proposal. In addition, the state of Tennessee lists species which are considered threatened, endangered, or in need of management (INM) in Tennessee [Tennessee Wildlife Resources Agency (TWRA) 1994a,b]. The state listing (Appendix A) includes federally listed species and others which are rare or declining in Tennessee. State law prohibits harming these species or their habitats without a permit. Thus, it is important that land managers know which state or federally listed species are present. Collectively, these species are termed threatened and endangered (T\&E) species in this report.

Previous studies on the Oak Ridge Reservation (ORR) provide some indication on what currently listed species might occur (Howell and Dunaway 1958, Howell 1958, Johnson 1964, Kitchings and Mann 1976, Kroodsma 1987, Klein 1989, Kroodsma 1993). However, some historical survey areas have been substantially altered since the studies were conducted, and not all currently listed species have been searched for. The objective of the current study, therefore, is to validate and expand on these earlier efforts.

Currently, there are 69 species of federally or state-listed terrestrial vertebrates ( 20 reptiles and amphibians, 20 mammals, and 29 birds) that may occur in Tennessee. Not all of these would be expected to occur on the ORR, nor did resources permit comprehensive sampling for all of them over the entire ORR. To effectively organize sampling efforts, we designated priorities for listed animal species which might be present based on historical and recent sightings, species distributions, literature reviews, and personal communications (Evans 1995, Klein 1995, Kroodsma 1995). For reptiles, amphibians, and mammals, the priorities were as follows:

Priority 1: species which have a range that extends into the ORR (reptiles and amphibians) or which have been found previously on the ORR (mammals);

Priority 2: $\quad$ species which have been found in counties adjacent to the ORR;

Priority 3: species which have been found in eastern Tennessee within 100 miles of the ORR.

For birds, prioritization was slightly different because these animals are particularly mobile and can be wide ranging (with range changes resulting from human activities) and are frequently migratory over long distances. The two priority categories established for birds are as follows:

Priority 1: $\quad$ species judged likely to be found on the ORR;

Priority 2: $\quad$ species for which adequate habitat exists on the ORR but which are currently uncommon in eastern Tennessee.

Sampling efforts were focused on these species according to priority. Tables 1,4 , and 7 list Priority 1 species; Tables 2, 5, and 8 list Priority 2 species; and Tables 3 and 6 list Priority 3 species 
(nonavian species only). Other federally and state-listed species which were not targeted for sampling are listed in Appendix B.

Table 1. Reptile and amphibian species which have a range that extends into the ORR (Priority 1)

\begin{tabular}{llll}
\hline \multicolumn{1}{c}{ Species } & Sampling Season & \multicolumn{1}{c}{ Habitat } & Sampling Technique \\
\hline $\begin{array}{l}\text { Tennessee cave } \\
\text { salamander }\end{array}$ & January-December & $\begin{array}{l}\text { Cave systems with } \\
\text { permanent streams; pools in } \\
\text { limestone }\end{array}$ & Survey cave \\
$\begin{array}{l}\text { Four-toed } \\
\text { salamander }\end{array}$ & September-March & $\begin{array}{l}\text { Hardwood forests near } \\
\text { sphagnum wetlands }\end{array}$ & $\begin{array}{l}\text { Pitfall traps, active } \\
\text { search, artificial cover, } \\
\text { seine, bottom nets }\end{array}$ \\
Hellbender & January-December & $\begin{array}{l}\text { Small rivers, large streams; } \\
\text { clear cool running water, } \\
\text { usually<20 C w/ flat rocks }\end{array}$ & $\begin{array}{l}\text { Electroshocking, } \\
\text { seining, potato rake, } \\
\text { active search }\end{array}$ \\
$\begin{array}{l}\text { Eastern slender } \\
\text { glass lizard }\end{array}$ & April-September & $\begin{array}{l}\text { Dry upland areas, brushy } \\
\text { cut-over woodlands, grassy } \\
\text { fields } \\
\text { Wooded hillsides, creeks, }\end{array}$ & $\begin{array}{l}\text { Artificial cover, active } \\
\text { search }\end{array}$ \\
Coal skink & April-September & $\begin{array}{l}\text { Artificial cover, active } \\
\text { search, pitfall traps }\end{array}$ \\
$\begin{array}{l}\text { Northern pine } \\
\text { snake }\end{array}$ & April-September & $\begin{array}{l}\text { Sandy pine woods, dry mt. } \\
\text { ridges, old fields with loose } \\
\text { soils; asphalt }\end{array}$ & $\begin{array}{l}\text { Artificial cover, active } \\
\text { search }\end{array}$ \\
\hline
\end{tabular}

Table 2. Reptile and amphibian species found in counties adjacent to the ORR (Priority 2)

\begin{tabular}{llll}
\hline \multicolumn{1}{c}{ Species } & Sampling Season & \multicolumn{1}{c}{ Habitat } & Sampling Technique \\
\hline $\begin{array}{l}\text { Black mountain } \\
\text { dusky salamander }\end{array}$ & April-October & $\begin{array}{l}\text { Under stones in association } \\
\text { with mountain brooks } \\
\text { with moderate to weak } \\
\text { currents }\end{array}$ & $\begin{array}{l}\text { Pitfall traps, funnel } \\
\text { traps, active search, } \\
\text { artificial cover }\end{array}$ \\
& & $\begin{array}{l}\text { Moist low-lying woodland } \\
\text { areas with ponds; terrestrial } \\
\text { adults live in subterranean } \\
\text { tunnels, under rotten logs, } \\
\text { debris, leaf-litter }\end{array}$ & $\begin{array}{l}\text { Seine, minnow traps, } \\
\text { bottom nets, pitfall } \\
\text { traps, artificial pools, } \\
\text { artificial cover }\end{array}$ \\
\hline
\end{tabular}

Table 3. Reptile and amphibian species found in eastern Tennessee (within 100 miles from the ORR) (Priority 3)

\begin{tabular}{|c|c|c|c|}
\hline Species & Sampling Season & Habitat & Sampling Technique \\
\hline Bog turtle & May-September & $\begin{array}{l}\text { Sphagnum wetlands, } \\
\text { swamps, meadows with clear } \\
\text { slow-moving streams with } \\
\text { muddy bottoms }\end{array}$ & Turtle traps, seine \\
\hline Green anole & April-September & $\begin{array}{l}\text { Trees, shrubs, vines, low } \\
\text { vegetation; nesting occurs in } \\
\text { dry rotting wood, leaf litter, } \\
\text { sphagnum or trash piles }\end{array}$ & $\begin{array}{l}\text { Pitfall traps, active } \\
\text { search }\end{array}$ \\
\hline
\end{tabular}

\footnotetext{
${ }^{1}$ This list excludes species found only in high elevations of the Smoky Mountains.
} 
Table 4. Mammal species which have been historically found on the ORR (Priority 1)

\begin{tabular}{llll}
\hline \multicolumn{1}{c}{ Species } & Sampling Season & \multicolumn{1}{c}{ Habitat } & Sampling Technique \\
\hline Gray bat & January-December & Caves & Survey caves, mist net \\
Smoky shrew & March-September & $\begin{array}{l}\text { Moist woodlands with rocks, } \\
\text { decaying logs, leaf-litter }\end{array}$ & $\begin{array}{l}\text { Sample wetlands with } \\
\text { pitfall traps }\end{array}$ \\
$\begin{array}{l}\text { Southeastern } \\
\text { shrew }\end{array}$ & March-September & $\begin{array}{l}\text { Flood plains, pine woods } \\
\text { with rocks, decaying logs, } \\
\text { leaf-litter }\end{array}$ & $\begin{array}{l}\text { Sample wetlands and } \\
\text { pines with pitfall traps }\end{array}$ \\
\hline
\end{tabular}

Table 5. Mammal species which have been found in counties adjacent to the ORR (Priority 2)

\begin{tabular}{|c|c|c|c|}
\hline Species & Sampling Season & Habitat & Sampling Technique \\
\hline Small-footed bat & January-December & Caves & Survey caves, mist net \\
\hline Indiana bat & January-December & Caves, large trees & Survey caves, mist net \\
\hline $\begin{array}{l}\text { Rafinesque's } \\
\text { big-eared bat }\end{array}$ & January-December & $\begin{array}{l}\text { Unoccupied man-made } \\
\text { structures, caves }\end{array}$ & $\begin{array}{l}\text { Survey abandon } \\
\text { buildings, caves, mist } \\
\text { net }\end{array}$ \\
\hline $\begin{array}{l}\text { Woodland } \\
\text { jumping mouse }\end{array}$ & August-September & $\begin{array}{l}\text { Spruce/fir, hemlock } \\
\text { hardwood forests, damp, } \\
\text { rocky, swampy areas }\end{array}$ & $\begin{array}{l}\text { Sample wetlands with } \\
\text { Sherman traps, pitfall } \\
\text { traps }\end{array}$ \\
\hline $\begin{array}{l}\text { Meadow jumping } \\
\text { mouse }\end{array}$ & August-September & $\begin{array}{l}\text { Open grassy areas with thick } \\
\text { vegetation near ponds, } \\
\text { streams, marshes }\end{array}$ & $\begin{array}{l}\text { Sample wetlands with } \\
\text { Sherman traps, pitfall } \\
\text { traps }\end{array}$ \\
\hline $\begin{array}{l}\text { Southern bog } \\
\text { lemming }\end{array}$ & January-December & $\begin{array}{l}\text { Open grassy areas with thick } \\
\text { vegetation near ponds, rocky } \\
\text { edges of streams, marshes, }\end{array}$ & $\begin{array}{l}\text { Sample wetlands with } \\
\text { Sherman traps, pitfall } \\
\text { traps }\end{array}$ \\
\hline Eastern wood rat & January-December & $\begin{array}{l}\text { Wooded, damp, rocky, } \\
\text { swampy areas }\end{array}$ & $\begin{array}{l}\text { Sample wetlands with } \\
\text { Sherman traps, pitfall } \\
\text { traps }\end{array}$ \\
\hline Masked shrew & March-October & $\begin{array}{l}\text { Moist woodlands with rocks, } \\
\text { decaying logs, leaf-litter }\end{array}$ & $\begin{array}{l}\text { Sample wetlands with } \\
\text { pitfall traps }\end{array}$ \\
\hline
\end{tabular}

Table 6. Mammal species found in eastern Tennessee (within 100 miles of the ORR) (Priority 3) ${ }^{1}$

\begin{tabular}{llll}
\hline \multicolumn{1}{c}{ Species } & Sampling Season & \multicolumn{1}{c}{ Habitat } & Sampling Technique \\
\hline Water shrew & March-October & $\begin{array}{l}\text { Moist woodlands with rocks, } \\
\text { decaying logs, leaf-litter, } \\
\text { rocky overhangs near } \\
\text { streams }\end{array}$ & $\begin{array}{l}\text { Sample wetlands } \\
\text { with pitfall traps }\end{array}$ \\
$\begin{array}{l}\text { Yellow-nosed } \\
\text { vole }\end{array}$ & March-October & $\begin{array}{l}\text { Moist woodlands with rocks, } \\
\text { decaying logs, leaf-litter }\end{array}$ & $\begin{array}{l}\text { Sample wetlands } \\
\text { with Sherman traps and } \\
\text { pitfall traps }\end{array}$ \\
\hline
\end{tabular}

\footnotetext{
${ }^{1}$ This list excludes species found only in high elevations of the Smoky Mountains.
} 
Table 7. Selected bird species most likely to be found on the ORR (Priority 1) ${ }^{1}$

\begin{tabular}{|c|c|c|c|}
\hline Species & Sampling Season & Habitat & Sampling Technique \\
\hline $\begin{array}{l}\text { Yellow-bellied } \\
\text { sapsucker }\end{array}$ & August-May & Open deciduous woods & $\begin{array}{l}\text { Locate signs-maple } \\
\text { trees }\end{array}$ \\
\hline Cooper's hawk & Year around & $\begin{array}{l}\text { Mixed or pine woods with } \\
\text { openings }\end{array}$ & Locate nest \\
\hline $\begin{array}{l}\text { Sharp-shinned } \\
\text { hawk }\end{array}$ & Year around & $\begin{array}{l}\text { Mixture of woods and open } \\
\text { country }\end{array}$ & Locate nest \\
\hline Great egret & July-September & Shorelines and wetlands & Locate specific habitat \\
\hline Northern harrier & Spring and Fall & $\begin{array}{l}\text { Marsh, open country and } \\
\text { weedy fields }\end{array}$ & Locate specific habitat \\
\hline Bald eagle & $\begin{array}{l}\text { Late summer and } \\
\text { winter }\end{array}$ & Open water; tall trees & $\begin{array}{l}\text { Search Clinch River } \\
\text { and Melton Hill Lake }\end{array}$ \\
\hline Osprey & May-October & Open water; platforms & $\begin{array}{l}\text { Search Clinch River } \\
\text { and Melton Hill Lake }\end{array}$ \\
\hline $\begin{array}{l}\text { Grasshopper } \\
\text { sparrow }\end{array}$ & April-September & Grassy fields, broom sedge & $\begin{array}{l}\text { Flushing, song } \\
\text { identification }\end{array}$ \\
\hline
\end{tabular}

${ }^{1}$ Sampling seasons are taken from Hamel 1992.

Table 8. Bird species for which adequate habitat exist on ORR but are uncommon in eastern Tennessee (Priority 2)

\begin{tabular}{llll}
\hline \multicolumn{1}{c}{ Species } & \multicolumn{1}{c}{ Sampling Season } & \multicolumn{1}{c}{ Habitat } & \multicolumn{1}{c}{ Sampling Technique } \\
\hline Snowy egret & July-September & $\begin{array}{l}\text { Marshes, lake margins and } \\
\text { wetlands }\end{array}$ & Locate specific habitat \\
Vesper sparrow & April-May; Oct-Nov & $\begin{array}{l}\text { Pastures, grasslands } \\
\text { with rocky hills }\end{array}$ & $\begin{array}{l}\text { Flushing, song } \\
\text { identification }\end{array}$ \\
$\begin{array}{l}\text { Common barn } \\
\text { owl }\end{array}$ & Year around & $\begin{array}{l}\text { Open country, marshes, } \\
\text { sheltered cavities }\end{array}$ & $\begin{array}{l}\text { Search buildings, use } \\
\text { calls }\end{array}$ \\
$\begin{array}{l}\text { Little blue heron } \\
\text { Double-crested } \\
\text { cormorant }\end{array}$ & July-September & Shorelines and wetlands & Locate specific habitat \\
$\begin{array}{l}\text { Olive-sided } \\
\text { flycatcher }\end{array}$ & Spring and Fall & Open water & $\begin{array}{l}\text { Search Clinch River } \\
\text { and Melton Hill Lake }\end{array}$ \\
$\begin{array}{l}\text { Sandhill crane } \\
\text { King rail }\end{array}$ & Spring and Fall & Openings and dead trees & Locate specific habitat \\
Least bittern & April-October & Marshes & Locate specific habitat \\
\hline
\end{tabular}

\footnotetext{
'Sampling seasons are taken from Hamel 1992
} 


\section{MATERIALS AND METHODS}

Sampling was conducted during the time of the year that each species would most likely be encountered. The selected sampling techniques were considered the most efficient methods available. Several trapping and surveying methods were used to conduct this survey; these methods are summarized in Tables 1 through 8 and are explained below.

\subsection{SELECTION OF SURVEY SITES}

To select survey sites for reptiles, amphibians and mammals, the ORR was divided into 10 compartments (Fig. 1). Five wetlands were selected in each compartment from Cunningham and Pounds (1991), based on professional judgement of their suitability (i.e. size and accessibility). Two sites were then chosen at random from the original five. Due to the lack of wetlands within compartments $\mathrm{H}$ and $\mathrm{F}$, only 17 sites were chosen (Appendices $\mathrm{C}$ and $\mathrm{D}$ ).

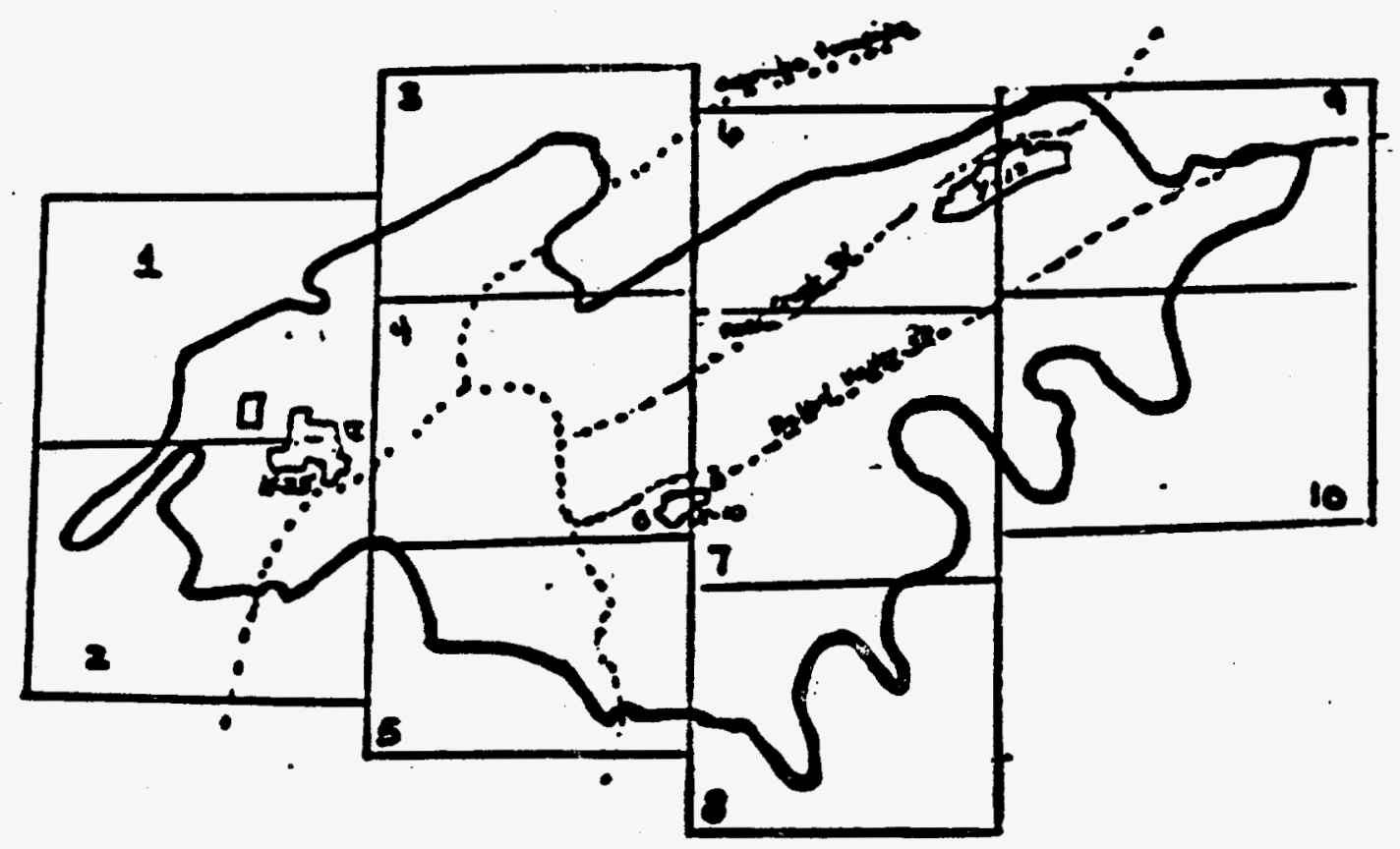

Fig. 1. Sampling compartments for reptiles, amphibians, and mammals on the ORR.

\subsection{TRAPPING AND SURVEY METHODS}

\subsubsection{Pitfall Traps}

The most effective way of capturing shrews and many amphibians is with pitfall or can traps (Karns 1986). Pitfall traps were suitable for some amphibian, reptile, and mammal species from all priority groupings; their use focused on the capture of the following animals: 
Priority 1: smoky shrew, southeastern shrew, four-toed salamander, coal skink

Priority 2: masked shrew, black mountain dusky salamander, mole salamander

Priority 3: water shrew, green anole

Placement of pitfall traps was in a standard grid pattern, surrounding the wetland with traps at 10-meter intervals (Fig. 2). The traps were \#10 cans buried in the ground deep enough for the tops to be flush with the surface (Fig. 3). All cans had holes for drainage; these traps were not baited. The total number of traps at each site varied with wetland size, but did not exceed 50. One week was allowed before trapping began for animals to adjust to habitat disturbances. During the trapping season (April-August), the traps were left open 24 hours a day for 3 consecutive days and were checked daily. When the traps were not in use they were deactivated by placing a stake into the can, thus allowing any captured animals to escape.

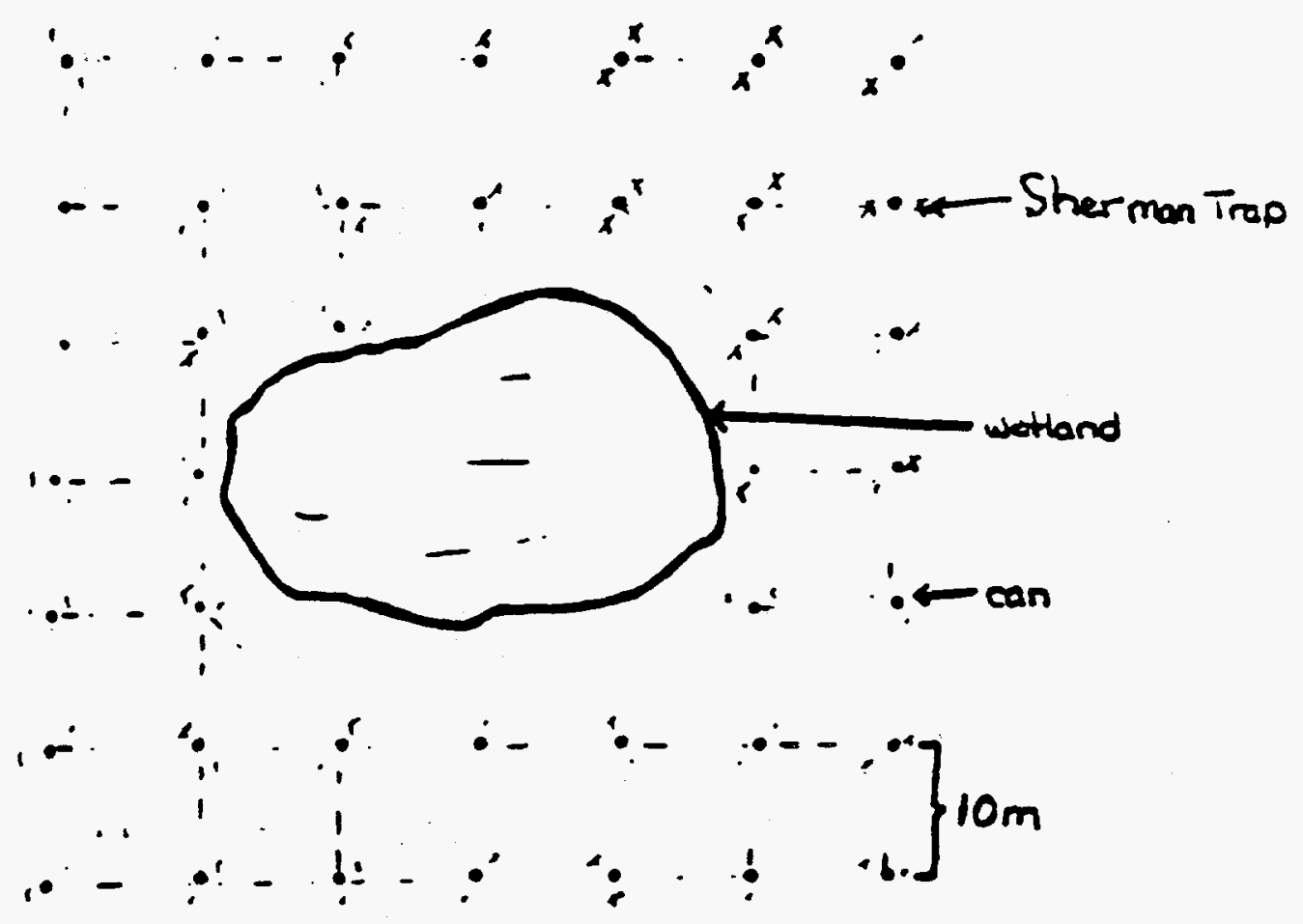

Fig. 2. Pitfall and Sherman trap grid placement. 


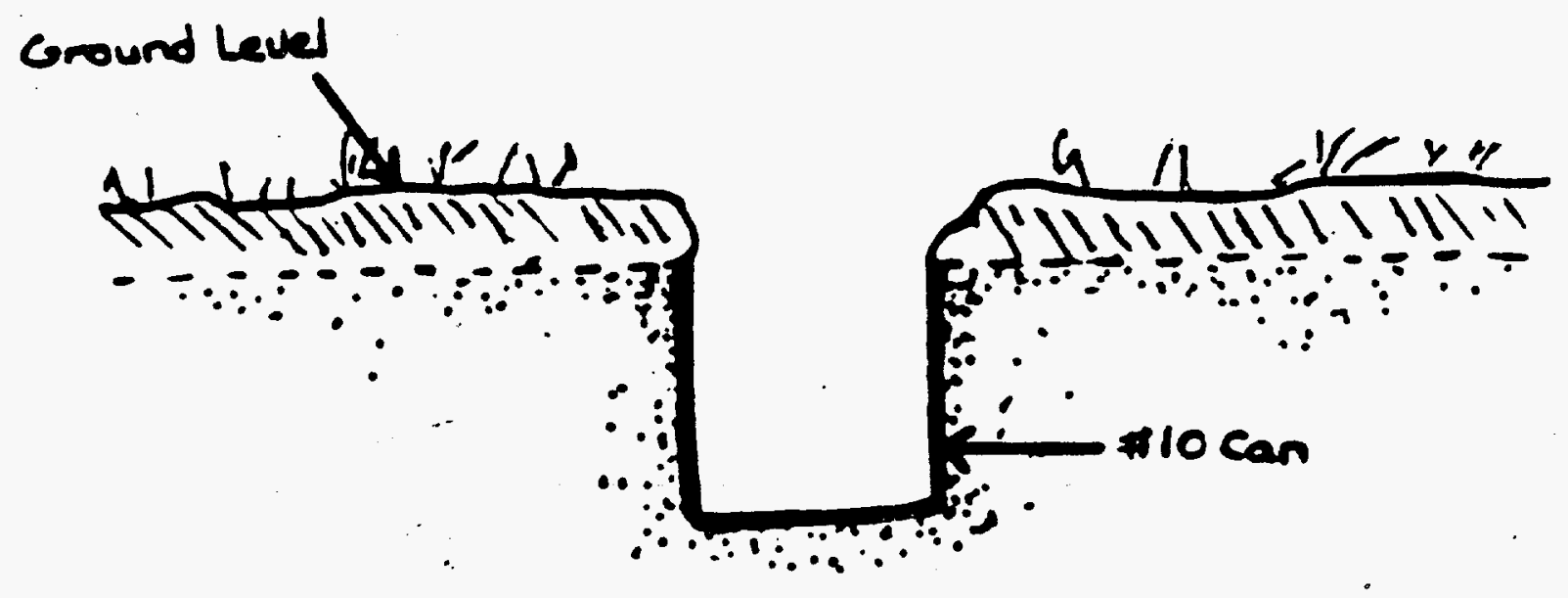

Fig. 3. Pitfall trap placement within the surface.

\subsubsection{Sherman Traps}

Sherman traps were suitable for Priority 2 and 3 mammal species; their use focused on the capture of the following mammals:

Priority 2: southern bog lemming, eastern wood rat, meadow jumping mouse and woodland jumping mouse

Priority 3: . yellow-nosed vole

The habitat requirements of these animals are very similar to the "pitfall" group; therefore, Sherman traps were placed in the previously established pitfall sites. Three to five sites were trapped per week. The trapping was timed with increased species activity (e.g., breeding season). One trap was placed within 2 meters of each pitfall trap (Fig. 2). The traps were placed near rocks, fallen logs, and animal runways. The total number of traps varied with wetland size but did not exceed 50 . The traps were baited with peanut butter and rolled oats. The traps were set in the afternoon of the first day, checked for 3 consecutive days, and then closed.

\subsubsection{Seining}

Seining is a quick and effective method of surveying amphibians in small ponds, wetlands and streams (Heyer et al. 1994). Semipermanent to permanent ponds within or near hardwood forests on the ORR were selected (Cunningham and Pounds 1991). This method was used to search for the mole salamander, a Priority 2 species.

A 4' $\times 8^{\prime}$ seine with a $1 / 8^{\prime \prime}$ mesh net was used. Transects were established in ponds out to a depth of 4 ' and parallel to the shoreline (Fig. 4) (Copperrider, Boyd, and Stuart 1986). Information collected at each pond was the seine width, transect length, water and air temperature, local weather condition, gender, and total number of each species collected. 


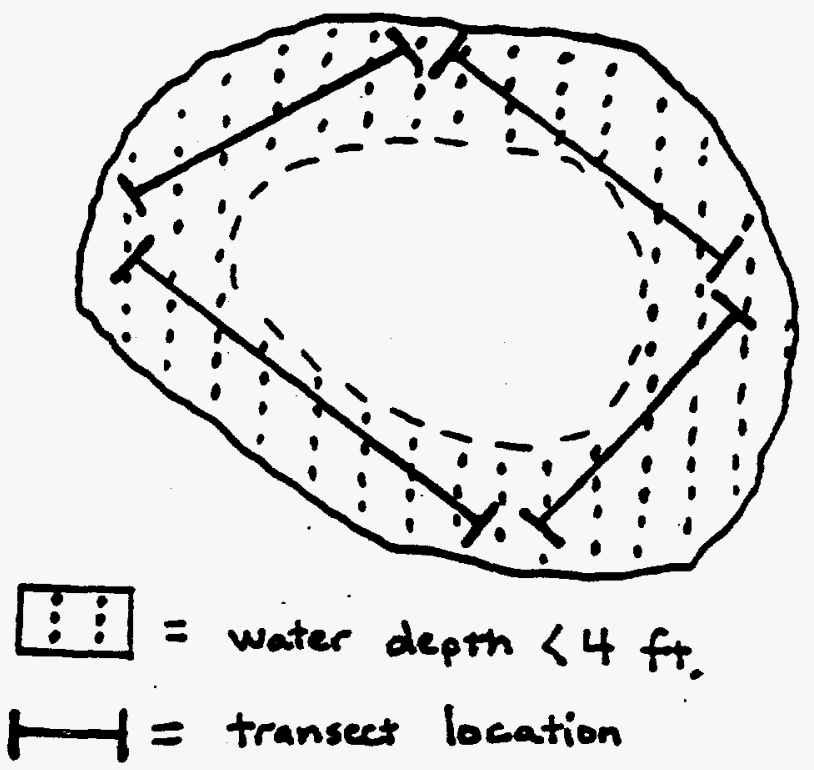

Fig. 4. Sampling design for pond seining.

\subsubsection{Artificial Covers (Boards)}

Artificial covers provide micro-habitats for a variety of animals from which they may be subsequently captured or identified. Covers are particularly suitable for encountering the following species:

Priority 1: eastern slender glass lizard and northern pine snake

Dry upland brushy habitats (e.g., power line rights-of-way, old fields) were selected to sample for the eastern slender glass lizard. Areas with pine stands or dry mountain ridges were selected for the northern pine snake. Artificial covers were constructed from scrap wood, approximately $3^{\prime} \times 3^{\prime}$ '. The wood was labeled, numbered, and monitored bimonthly during the appropriate sampling seasons (April-September). The artificial covers sites were located at Freels Bend, Bull Bluff, Gas Line Road, and McCoy Branch (Appendices C and D). Artificial covers were placed in appropriate sites in groups of 20 .

\subsubsection{Cave Entry}

Cave entry was necessary to conduct surveys for the following species:

Priority 1: gray bat, Tennessee cave salamander

Priority 2: $\quad$ small-footed bat, Indiana bat, Rafinesque's big-eared bat

Currently 32 caves have been located on the reservation (Appendices $\mathrm{E}$ and $\mathrm{F}$ ). Time restrictions only allowed for entry into five caves. Active searching was the sampling method. 


\subsubsection{Avian Survey}

Most bird surveys used an active search approach, whereby the preferred habitat of each species is searched visually (using binoculars or spotting scope) and auditorially for their presence. In addition, some point counts were conducted in varied habitats across the reservation. The counts were conducted along old roads, trails, or in the middle of a specified habitat. As many habitat types as possible were covered. Thirteen routes were chosen across the reservation, each 2 to 4 miles long. Stopping points were located every $1 / 6$ mile. At these points, all birds seen or heard were recorded (Hamel et al. 1994). The routes were surveyed in June, the prime nesting season for many species.

\subsection{HABITAT ANALYSIS}

Habitat analysis will be conducted at each of the 17 survey sites for reptiles, amphibians, and mammals. Variables to be recorded are given in Appendices $\mathrm{G}$ and $\mathrm{H}$. This analysis will be taken to document changes over time in the event that future surveys are conducted. This general information will provide some habitat characteristics for areas where T\&E species are located.

\subsection{DOCUMENTATION}

Information on captured animals was recorded on data sheets (Appendix $\mathrm{H}$ ). In cases where identification could not be made in the field, the specimen was taken to the laboratory for further study. A photograph of each specimen was taken to document identification. Records, photos and identifications were also kept for nontargeted and unlisted species.

\section{RESULTS}

\subsection{RESULTS FOR 1994}

Appendix I lists the seven protected species located on the reservation during the 1994 sampling season, and Appendix J lists previous listed species (subsequently delisted) located in 1994.

Fiscal year 1994 results are published in Environmentally Sensitive Areas Surveys Program, Threatened and Endangered Species Survey Progress Report, ES/ER/TM-130 (Martin Marietta Energy Systems, Inc. 1994).

\subsection{RESULTS FOR 1995}

\subsubsection{Reptiles and Amphibians}

Thirty-seven species were observed/collected from October 1994 through September 1995. The coal skink (Eumeces anthracinus) was the only T\&E species provisionally collected (Table 9). (A record is considered provisional when it cannot be independently verified by photograph or specimen). The coal skink feeds primarily upon insects; its habitat includes creeks, wooded hillsides, and rocky outcrops. Five different observation/collection methods were used: seining ponds, active searching, boards, pitfall traps, and Sherman traps (Table 9). 
A particular effort was made to locate the listed and targeted mole salamander (Priority 1). Twenty ponds across the reservation were seined to sample for adult mole salamanders during the months of January-March 1995. Most ponds were abandoned cattle ponds surrounded by mixed pine/hardwood forest and old fields. Due to icing of the ponds it was not possible to revisit any sites. No mole salamanders were recovered, possibly also due to unfavorable weather.

Table 9. Reptiles and amphibians observed/collected on the ORR from October 1994 to September 1995. Bold entries indicate a listed species; a "?" indicates a provisional (unverified) record

\begin{tabular}{|c|c|c|c|c|}
\hline Common Name & Genus Species & Site Location & $\begin{array}{l}\text { Collection } \\
\text { Method }\end{array}$ & Date Observed \\
\hline Red-spotted newt & $\begin{array}{l}\text { Notophthalmus } \\
\text { viridescens } \\
\text { viridescens }\end{array}$ & $\begin{array}{l}\text { McCoy Branch, Freels Bend, } \\
\text { Bethel Valley, Y-12 Burial } \\
\text { Grounds, Y-12 Sludge Field, } \\
\text { Meteorological Tower }\end{array}$ & Seining & $\begin{array}{l}\text { January-March } \\
1995\end{array}$ \\
\hline $\begin{array}{l}\text { S. Mountain } \\
\text { dusky }\end{array}$ & $\begin{array}{l}\text { Desmognathus } \\
\text { ochrophaeus }\end{array}$ & $\begin{array}{l}\text { Melton Valley, E. Fork } \\
\text { Poplar Cr. }\end{array}$ & Active Search & May, July 1995 \\
\hline $\begin{array}{l}\text { N. Red } \\
\text { salamander }\end{array}$ & $\begin{array}{l}\text { Psedotritonruber } \\
\text { ruber ssp. }\end{array}$ & $\begin{array}{l}\text { Melton Valley, E. Fork } \\
\text { Poplar Cr. }\end{array}$ & Active Search & $\begin{array}{l}\text { May-August } \\
1995\end{array}$ \\
\hline $\begin{array}{l}\text { N. Dusky } \\
\text { salamander }\end{array}$ & $\begin{array}{l}\text { Desmognathusfuscus } \\
\text { ssp. }\end{array}$ & $\begin{array}{l}\text { Melton Valley, E. Fork } \\
\text { Poplar Cr. }\end{array}$ & Active Search & $\begin{array}{l}\text { May, August } \\
1995\end{array}$ \\
\hline $\begin{array}{l}\text { S. Two-lined } \\
\text { salamander }\end{array}$ & Euyce cirrigera & Muskrat Marsh, Melton Valley & Active Search & $\begin{array}{l}\text { November } 1994, \\
\text { May } 1995\end{array}$ \\
\hline $\begin{array}{l}\text { N. Spring } \\
\text { salamander }\end{array}$ & $\begin{array}{l}\text { Gyrinophilus } \\
\text { porphyriticus } \\
\text { porphyriticus ssp. }\end{array}$ & Cooper Ridge Cave & Active Search & April 1995 \\
\hline $\begin{array}{l}\text { N. Slimy } \\
\text { salamander }\end{array}$ & Plethodon glutinosus & $\begin{array}{l}\text { Cooper Ridge Cave, Flash } \\
\text { Light Heaven Cave, Pinnacle } \\
\text { Cave }\end{array}$ & Active Search & $\begin{array}{l}\text { January, June } \\
1995\end{array}$ \\
\hline Cave salamander & Eurycea lucifuga & $\begin{array}{l}\text { Copper Ridge Cave, Flash } \\
\text { Light Heaven Cave, Pinnacle } \\
\text { Cave, Melton Valley, E. Fork } \\
\text { Poplar Cr. }\end{array}$ & Active Search & $\begin{array}{l}\text { January, June } \\
1995\end{array}$ \\
\hline Six-lined racer & $\begin{array}{l}\text { Cnemidophorus } \\
\text { sexlineatus } \\
\text { sexlineatus }\end{array}$ & E. Fork Poplar Cr. & Active Search & August 1995 \\
\hline $\begin{array}{l}\text { S. Five-lined } \\
\text { skink }\end{array}$ & $\begin{array}{l}\text { Eumeces } \\
\text { inexpectatus }\end{array}$ & $\begin{array}{l}\text { Muskrat Marsh, Freels Bend, } \\
\text { Walker Branch }\end{array}$ & Active Search & $\begin{array}{l}\text { October 1994, } \\
\text { May-September } \\
1995\end{array}$ \\
\hline ?Coal skink ${ }^{1}$ & $\begin{array}{l}\text { Eumeces } \\
\text { anthracinus ssp. }\end{array}$ & Freels Bend & Pitfall Traps & August 1995 \\
\hline Ground skink & Scinella lateralis & Melton Valley, Freels Bend & Pitfall Traps & May-July 1995 \\
\hline Fence lizard & $\begin{array}{l}\text { Sceloporus } \\
\text { undulatus } \\
\text { hyacinthinus ssp. }\end{array}$ & Freels Bend & Active Search & $\begin{array}{l}\text { July-August } \\
1995\end{array}$ \\
\hline Black rat snake & $\begin{array}{l}\text { Elaphe obsoleta } \\
\text { obsoleta }\end{array}$ & $\begin{array}{l}\text { Shepherd's Cem., Gasline Rd., } \\
\text { Freels Bend }\end{array}$ & Boards & June-July 1995 \\
\hline N. Copperhead & $\begin{array}{l}\text { Aglcistrodon } \\
\text { contortix mokasen }\end{array}$ & Freels Bend, Walker Branch & Active Search & $\begin{array}{l}\text { July-August } \\
1995\end{array}$ \\
\hline
\end{tabular}


Table 9 cont.

\begin{tabular}{|c|c|c|c|c|}
\hline Common Name & Genus Species & Site Location & $\begin{array}{l}\text { Collection } \\
\text { Method }\end{array}$ & Date Observed \\
\hline Black king snake & $\begin{array}{l}\text { Lampropeltis getula } \\
\text { nigra }\end{array}$ & $\begin{array}{l}\text { Freels Bend, McCoy Branch, } \\
\text { Bull Bluff }\end{array}$ & Boards & $\begin{array}{l}\text { June-September } \\
1995\end{array}$ \\
\hline E. Worm snake & $\begin{array}{l}\text { Carphophis amoneus } \\
\text { amoneus ssp. }\end{array}$ & $\begin{array}{l}\text { Shepherd's Cem., Muskrat } \\
\text { Marsh, McNew Hollow, Bear } \\
\text { Cr. }\end{array}$ & Boards & $\begin{array}{l}\text { May-August } \\
1995\end{array}$ \\
\hline N. Water snake & $\begin{array}{l}\text { Nerodia sipedon } \\
\text { sipedon ssp. }\end{array}$ & McCoy Branch, Bull Bluff & $\begin{array}{l}\text { Boards, Active } \\
\text { Search }\end{array}$ & $\begin{array}{l}\text { June-September } \\
1995\end{array}$ \\
\hline N. Brown snake & $\begin{array}{l}\text { Storeria dekayi } \\
\text { dekayi ssp. }\end{array}$ & Gasline Rd. E. Fork Poplar Cr. & Boards & May, July 1995 \\
\hline S. Ringneck snake & $\begin{array}{l}\text { Diadophis punctatus } \\
\text { punctatus ssp. }\end{array}$ & McNew Hollow, Bull Bluff & Boards & $\begin{array}{l}\text { October } 1994, \\
\text { September } 1995\end{array}$ \\
\hline Corn snake & $\begin{array}{l}\text { Elaphe guttata } \\
\text { guttata }\end{array}$ & Freels Bend & Active Search & September 1995 \\
\hline N. Black racer & $\begin{array}{l}\text { Coluber constrictor } \\
\text { constricor } \mathrm{ssp} .\end{array}$ & Gasline Rd. & Boards & $\begin{array}{l}\text { May-August } \\
1995\end{array}$ \\
\hline E. Garter snake & $\begin{array}{l}\text { Thamnophis sirtalis } \\
\text { sirtalis ssp. }\end{array}$ & McCoy Branch, Bull Bluff & Boards & $\begin{array}{l}\text { June-August } \\
1995\end{array}$ \\
\hline S. Leopard frog & Rana utricularia & $\begin{array}{l}\text { Freels bend, Y-12 Burial } \\
\text { Grounds, Meteorological } \\
\text { Tower, Flashlight Heaven } \\
\text { Cave, Perimeter Rd. }\end{array}$ & $\begin{array}{l}\text { Pitfall Traps, } \\
\text { Sherman Traps }\end{array}$ & $\begin{array}{l}\text { March, June, } \\
\text { August } 1995 \\
\text { May-August } \\
1995\end{array}$ \\
\hline Bull frog & Rana catesbeiana & $\begin{array}{l}\text { Muskrat Marsh, Burns Cem., } \\
\text { Freels Bend, Check Station }\end{array}$ & $\begin{array}{l}\text { Pitfall Traps, } \\
\text { Active Search, } \\
\text { Seining }\end{array}$ & $\begin{array}{l}\text { October- } \\
\text { November 1994, } \\
\text { April, August } \\
1995\end{array}$ \\
\hline Gray tree frog & Hyla versicolor & 0800 & Active Search & April 1995 \\
\hline Spring peeper & $\begin{array}{l}\text { Pseudacris crucifer } \\
\text { ssp. }\end{array}$ & McCoy Branch & Active Search & April 1995 \\
\hline Green tree frog & Hyla cinerea & Freels Bend & Seining & January 1995 \\
\hline $\begin{array}{l}\text { Upland chorus } \\
\text { frog }\end{array}$ & $\begin{array}{l}\text { Pseudacris triseriata } \\
\text { feriarum }\end{array}$ & McNew Hollow & Active Search & March 1995 \\
\hline American toad & $\begin{array}{l}\text { Bufo americanus } \\
\text { ssp. }\end{array}$ & $\begin{array}{l}\text { Meteorological Tower, } \\
\text { McNew Hollow, Perimeter Rd. }\end{array}$ & $\begin{array}{l}\text { Active Search, } \\
\text { Pitfall Traps }\end{array}$ & $\begin{array}{l}\text { March-June } \\
1995\end{array}$ \\
\hline $\begin{array}{l}\text { E. Narrow- } \\
\text { mouthed toad }\end{array}$ & $\begin{array}{l}\text { Gastrophryne } \\
\text { carolinensis }\end{array}$ & Roger's Quarry, Freels Bend & Boards & June 1995 \\
\hline Snapping turtle & $\begin{array}{l}\text { Chelydra serpentina } \\
\text { ssp. }\end{array}$ & Freels Bend, Wood Duck Pond & Active Search & $\begin{array}{l}\text { January, August } \\
1995\end{array}$ \\
\hline $\begin{array}{l}\text { Spiny softshell } \\
\text { turtle }\end{array}$ & $\begin{array}{l}\text { Abalone spinifera } \\
\text { spinifera }\end{array}$ & K-25, Freels Bend & Active Search & $\begin{array}{l}\text { May-September } \\
1995\end{array}$ \\
\hline Red-eared slider & $\begin{array}{l}\text { Trachemys scripta } \\
\text { elegans ssp. }\end{array}$ & Freels Bend & Active Search & July 1995 \\
\hline
\end{tabular}


Table 9 cont.

\begin{tabular}{|c|c|c|c|c|}
\hline Common Name & Genus Species & Site Location & $\begin{array}{l}\text { Collection } \\
\text { Method }\end{array}$ & Date Observed \\
\hline $\begin{array}{l}\text { Midland painted } \\
\text { turtle }\end{array}$ & $\begin{array}{l}\text { Chrysemys picta } \\
\text { marginata }\end{array}$ & Freels Bend & Active Search & July 1995 \\
\hline E. Box turtle & $\begin{array}{l}\text { Terrapene carolina } \\
\text { carolina ssp. }\end{array}$ & $\begin{array}{l}\text { Walker Branch, E. Fork Poplar } \\
\text { Cr., Freels Bend, Bull Bluff, } \\
\text { Shepherd's Cem., McNew } \\
\text { Hollow, Perimeter Rd., Burns } \\
\text { Cem. }\end{array}$ & Active Search & $\begin{array}{l}\text { July-August } \\
1995\end{array}$ \\
\hline
\end{tabular}

'In need of management species.

\subsubsection{Mammals}

The following 15 species were collected during October 1994 through September 1995: white-footed mouse, deer mouse, eastern harvest mouse, golden mouse, southeastern shrew, least shrew, short-tailed shrew, eastern chipmunk, pine vole, meadow vole, hispid cotton rat, gray bat, raccoon, eastern cottontail rabbit, and opossum. Of the $13 \mathrm{~T} \& \mathrm{E}$ and in-need-of-management species targeted in this plan, 2 were located.

A gray bat (Mytosis grisescens, federally endangered) was collected from the Oak Ridge Y-12 Plant on October 31, 1994. A second possible (unverified) gray bat was collected from the Y-12 Plant on August 1, 1995. Gray bats roost in caves with vertical openings and feed mainly on night-flying insects (Harvey 1992).

The southeastern shrew (Sorex longirostris, state in need of management) was collected from eight locations from May through July 1994 (Table 10). Southeastern shrews are insectivores, living mainly in wetland habitats (Eagar and Hatcher 1980). They had been historically documented on the ORR by Howell and Dunaway (1958), captured in jar traps along White Oak Lake.

Table 10. Southeastern shrews (Sorex longirostris) captured in pitfall traps on the ORR from February through September 1995, by collection site

\begin{tabular}{lcc}
\hline \multicolumn{1}{c}{ Collection Site } & Date & No. Collected \\
\hline Muskrat Marsh & May 10, 1995 & 2 \\
Melton Valley & May 10, 1995 & 1 \\
Wood Duck Pond & May 10, 1995 & 1 \\
Wood Duck Pond & May 12, 1995 & 2 \\
Check Station & June 6, 1995 & 1 \\
Check Station & June 28, 1995 & 1 \\
ORNL & July 12, 1995 & 1 \\
E. Fork Poplar Cr. & July 20, 1995 & 1 \\
Check Station & July 31, 1995 & 1 \\
Bear Creek & September 26, 1995 & 1 \\
Mc New Hollow & September 26, 1995 & 1 \\
\hline
\end{tabular}




\subsubsection{Cave Entry}

Surveying 5 of the 32 caves on the reservation occurred from February through September 1995 (Appendices $\mathrm{E}$ and F). The cave salamander, slimy salamander, eastern pipistrel, big brown bat, and southern leopard frog were observed in the caves.

\subsubsection{Avian Surveys}

All bird species recorded during the breeding bird census are listed in Table 11. Records of T\&E birds that have been found on the ORR are listed below. The header contains the following information: species' common name, scientific name, state or federal status, and four-letter species code. Several species have multiple sightings. Included in the sighting report is the date of observation, location of observation, number and gender observed, and observer's name(s). Appendix $\mathrm{K}$ lists affiliations of observers.

Below the sightings records, accounts are given for each species. The accounts include how commonly the species occurs on the ORR, nesting records, state distributions, and any conclusive historical records.

Table 11. Birds observed during 1995 breeding census on the ORR

\begin{tabular}{lll}
\hline Great blue heron & Downy woodpecker & Northern parula \\
Great egret* & Hairy woodpecker & Yellow-throated warbler \\
Little blue heron* & Northern (yellow-shafted) flicker & Pine warbler \\
Green-backed heron & Pileated woodpecker & Prairie warbler \\
Black-crowned night heron & Eastern wood-peewee & Black-and-white warbler \\
Canada goose & Acadian flycatcher & Ovenbird \\
Wood duck & Eastern phoebe & Kentucky warbler \\
Black vulture & Great crested flycatcher & Common yellowthroat \\
Osprey* & Eastern kingbird & Hooded warbler \\
Sharp-shinned hawk* & Tree swallow & Yellow-breasted chat \\
Red-shouldered hawk & Northern rough-winged swallow & Summer tananger \\
Red-tailed hawk & Cliff swallow & Scarlet tananger \\
American kestrel & Barn swallow & Northern cardinal \\
Wild turkey & Blue jay & Blue grosbeak \\
Northern bobwhite & American crow & Indigo bunting \\
Killdeer & Carolina chickadee & Rufous-sided towhee \\
American woodcock & Tufted titmouse & Chipping sparrow \\
Rock dove & White-breasted nuthatch & Field sparrow \\
Mourning dove & Carolina wren & Grasshopper sparrow* \\
Yellow-billed cuckoo & Blue-gray gnatcatcher & Song sparrow \\
Great horned owl & Eastern bluebird & Red-winged blackbird \\
Barred owl & Wood thrust & Eastern meadowlark \\
Chuck-will's-widow & American robin & Common grackle \\
Whippoorwill & Brown thrasher & Brown-headed cowbird \\
Chimney swift & Cedar waxwing & Orchard oriole \\
Ruby-throated hummingbird & European starling & House finch \\
Belted kingfisher & White-eyed vireo & American goldfinch \\
Red-bellied woodpecker & Red-eyed vireo & \\
\hline
\end{tabular}

*Listed species 
Sharp-shinned hawk (Accipiter striatus) INM, SSHA

5/25/95 K-25 Site Visitor Overlook, 1 female, Blymiller

6/13/95 East Fork Poplar Creek (Duck Island), 1 male, Evans/Mitchell

6/16/95 East Fork Area (Herrell Road), 1 male, Evans/Mitchell

6/19/95 Bull Bluff Road, 1 male (carcass), Evans/Mitchell

6/19/95 K-25 Site Visitor Overlook, 1 male, Blymiller

6/29/95 East Fork Area (Herrell Road), 1 male, Mitchell

8/14/95 Freels Bend, 1 male, Mitchell/Evans

8/15/95 Walker Branch Road, 1 male, Evans

8/29/95 East Fork Poplar Creek (Gallaher Cemetery), 1 female, Mitchell/Vail

9/05/95 Freels Bend, 1 male, Evans

Common. The SSHA is a known permanent resident of the ORR. Male and female birds were sighted reservation-wide during the 1995 breeding season. Record: One previous nest location was reported in 1994 near the Jones Island area of Clinch River. The nest was located near Raccoon Creek on the TVA boundary line/gas line (Kroodsma 1995).

\section{Cooper's hawk (Accipiter cooperii) INM, COHA}

8/22/94 K-25 Site Portal 4, 1 juvenile, Evans/Blymiller

2/22/95 Bethel Valley Road, 1 male, Vail/Mitchell

3/12/95 Gasline Road, 1 individual, Evans/Mitchell

5/19/95 K-25 Site Area Grounds, 1 individual, Blymiller

3/07/95 K-25 Site 1330 Area, 1 individual, Blymiller

8/08/95 K-25 Site 1330 Area, 1 individual, Blymiller

8/11/95 Y-12 Lake Reality, 1 individual (immature), Evans/Roy

Common. The COHA is a known permanent resident of the reservation. Juvenile birds were sighted during the 1994 and 1995 breeding seasons.

\section{Grasshopper sparrow (Ammodramus savannarum) INM, GRSP}

5/08/95 Freels Bend-Clinch River, 1 individual, Mitchell

5/12/95 Freels Bend-Clinch River, 2 individuals, Ryon/Schilling/Carricco/Roy/Webb/Mitchell

5/8-8/30/95 Freels Bend-Clinch River, 2-10 individuals, Mitchell/Vail

Uncommon to rare on the ORR. Common in the region. The GRSP was found in one location on the ORR. Eight to ten birds were observed nesting in the Freels Bend area. This bird is likely to be found in other areas of the reservation where suitable habitat is maintained. Record: This species was reported during the breeding season in the area between the Y-12 Plant and Bethel Valley Road (Kroodsma 1987).

\section{Anhinga (Anhinga anhinga) INM, ANHI}

6/20/94 ORNL Swan Pond, 1 individual, Lane/O’Neil/Wojtowicz/Wilkerson

Rare transient. One recent record is known for the ANHI on the ORR. This bird was observed at the ORNL Swan Pond. This species is more often found in west Tennessee (Robinson 1990). 
Great egret (Casmerodius albus) INM, GREG

6/11/94 Poplar Creek (near water tower), 1 individual, Evans/Mitchell

6/28/95 Poplar Creek (near boat launch), 1 individual, Evans/Herd

7/06/95 K-25 Site Beaver Ponds (near old salvage buildings), 1 individual, Evans/Mitchell

7/10-8/17/95 ORNL Swan Pond, 1-5 individuals, Evans, Roy, Mitchell

7/26/95 ORNL Swan Pond, 5 individuals, Webb/Mitchell

7/29/95 White Oak Lake Embayment, 2 individuals, Gehl, Evans, Mitchell

7/31/95 Freels Bend Land Bridge, 1 individual, Vail/Gehl

8/01/95 Freels Bend Land Bridge, 1 individual, Evans/Gehl

8/07/95 Freels Bend Land Bridge, 1 individual, Mitchell/Vail/Webb

8/11/95 K-25 Site K-901A Pond, 1 individual, Evans/Roy

8/14/95 Freels Bend Land Bridge, 1 individual, Evans/Mitchell

8/15/95 K-25 Site K-901A Pond, 1 individual, Mitchell

9/05/95 ORNL Swan Pond, 1 individual, Mitchell/Evans/Vail

Common migrant. The GREG can be found in several areas across the reservation during post-breeding dispersal.

\section{Northern harrier (Circus Cyanus) INM, NOHA}

9/7/94 McNew Hollow/Hembree Marsh, 1 individual, Mitchell

9/9/94 Raccoon Creek, 1 individual, Vail/Mitchell

9/20/94 0800 Area (along Clinch River), 1 male and 1 female, Vail/Mitchell

Common migrant. The NOHA has been sighted in three locations on the ORR. This secretive hawk is probably more common than records suggest. This species is not known to nest in this area and is considered a spring and fall migrant.

Olive-sided flycatcher (Contopus borealis) INM, OSFL

5/12/95, Freels Bend Road, 1 individual, Ryon/Roy/Schilling/Carricco

5/15/95, Freels Bend Road, 1 individual, Mitchell

Rare spring and fall migrant. Two sightings of the same bird exist for the OSFL. This species uses the ORR as a "stopover" as it travels to and from its nesting grounds in the boreal forest. Summer records have been reported from the Great Smoky Mountains National Park (Robinson 1990).

\section{Little blue heron (Egretta caerulea) INM, LBHE}

7/06/95 K-25 Site Beaver Pond (near old salvage buildings), 1 individual (immature), Evans/Mitchell

7/17/95 K-25 Site-K-901A Pond, 1 individual (immature), Geh1/Mitchell/Evans

7/18/95 K-25 Site-K-901A Pond, 1 individual (immature), Roy/Schilling/McCracken/Gehl/Mitchell

7/29/95 White Oak Lake Embayment, 1 individual (immature), Evans/Geh1/Mitchell

8/11/95 White Oak Lake Embayment, 1 individual (immature), Evans/Roy

8/31/95 White Oak Lake Embayment, 1 individual (immature), Evans/Roy

Uncommon to rare. Late summer visitor. Several sightings of what appeared to be only one LBHE were record in 1995. This bird was spotted in several wetlands across the ORR. 


\section{Sandhill crane (Grus candensis) INM, SACR}

3/05/95 East Fork-K-25 Site Overlook, 1 individual, Evans/Mitchell

Uncommon spring and fall migrant. One current record exist for the SACR on the ORR. The bird landed in Poplar Creek, probably migrating north. Each year, reports are given on numbers of SACR observed flying over the ORR.

\section{Double-crested cormorant (Phalacrocorax auritus) INM, DCCO}

6/94 ORNL Swan Pond, 1 individual, Mitchell

5/05/95 Melton Hill Lake (near Consolidated Fuel Recycling Facility), 20-25 individuals, Brewer 5/12/95 Melton Hill Lake (near Consolidated Fuel Recycling Facility), 20-25 individuals, Brewer 7/05/95 Clinch River (near K-25 Site powerhouse), 1 individual, Brewer/Mitchell

8/31/95 Poplar Creek (west end), 2 individuals (immature), Evans/Roy

Common migrant. The DCCO has been observed using the Melton Hill Lake area. A group of 20-25 individuals used the islands around the Consolidated Fuel Recycling Facility for several weeks. This species may soon be observed more often as nesting success increases over the next few years. One juvenile was observed on Clinch River near the K-25 Site.

Yellow-bellied sapsucker (Sphyrapicus varius) INM, YBSA

2/23/95 Walker Branch, 1 individual, Mitchell

3/27/95 Walker Branch Road, 1 individual, Mitchell/Rathmell/Vail

Common winter resident. The YBSA is a winter resident of the ORR. Two records were taken during the 1995 survey. Ample habitat exist for this species on the reservation and "sapsucker holes" can be observed in many locations across the ORR.

\section{Peregrine falcon (Falco peregrinus) FT, PEFA}

5/15/95 Flyover ORR (west end), 1 individual, Kroodsma

Rare migrant. One sighting exists for this species. A bird was observed flying over the ORR.

\section{Bald eagle (Haliaeetus leucocephalus) FT, BAEA}

8/09/94 Jones Island Road-Clinch River, 1 adult, Combs/Gehl/Osburn 8/11/94 Jones Island Road-Clinch River, 1 adult, Combs/Gehl/Osburn

Uncommon migrant. The BAEA has been documented using the ORR. Suitable habitat exists on the ORR side of Clinch River for this species. Given the expansion of the eagle breeding population in Tennessee and the introduction efforts in eastern Tennessee, establishment of a breeding population may occur on the ORR without proactive management (Buehler 1994).

\section{Osprey ( Pandion haliaetus) ST, OSPR}

6/07/94 K-25 Site Lagoon 1505, 1 individual, Mitchell

6/11/94 Poplar Creek (East), 1 individual, Evans/Mitchell

5/24/95 White Oak Lake Embayment, 1 individual, Evans/Roy 
5/31/95 Freels Bend (South), 1 individual, Mitchell

6/27/95 Freels Bend (South), 1 individual, Mitchell

6/29/95 Poplar Creek (East), 2 adults-2 chicks, Mitchell

7/18/95 Poplar Creek (East), 2 adults-2 chicks, Mitchell

Common nester. OSPR nesting records have existed on the ORR for several years. The establishment of platforms in the Clinch River and Melton Hill Lake areas have been successful in providing nesting sites.

\section{FUTURE WORK}

Research will continue from October 1995 to May 1996. Sampling plans and other work for this period are given below.

- To survey for the woodland and meadow jumping mice, sites will be selected in large open fields. Sites will be located at Freels Bend ( 2 sites), Wood Duck Pond (1 site), 0800 Area (2 sites) and K-25 Site Salvage ( 2 sites). Sherman traps will be placed in transects within each area, with no more than 50 traps per site. The traps will be monitored as during the previous season.

- Pitfall and Sherman trap surveys will continue in sites where the southeastern shrew or the masked shrew have not yet been captured.

- Cave surveys will continue for the Tennessee cave salamander.

- Habitat analysis will be conducted at all previous and new sites. This will include GPS information and the mapping of the sites.

- Active searches will continue at various locations for reptiles and amphibians on the ORR.

- Bird surveys will continue with winter point counts, monitoring of the fall and spring migration, and a bald eagle count.

- A final report will be prepared.

\section{REFERENCES}

Buehler, D. A. 1994. Bald Eagle Habitat Suitability on Melton Hill Reservoir and the Clinch River, ORNL/NEAP-9, Pub. No. 4248, Oak Ridge National Laboratory, Oak Ridge, Tennessee, p. 38.

Copperrider, A. Y., R. J. Boyd, and H .R. Stuart, eds. 1986. Inventory and Monitoring of Wildlife Habitat, U.S. Dept. of the Interior, Bureau of Land Management Service Center, Denver, Colo., p. 858.

Cunningham, M., and L. Pounds 1991. Vol. 28: Wetlands on the Oak Ridge Reservation, ORNL/NERP-5, Oak Ridge National Laboratory, Oak Ridge Tennessee, p. 32.

Eagar, D. C., and R. M. Hatcher, eds. 1980. Tennessee's Rare Wildlife, Vol. 1: The Vertebrates, Tennessee Wildlife Resources Agency and Tennessee Department of Environment and Conservation, Nashville, Tenn. 
Evans, J. W. (TWRA) January 1995. Personal Communication with J. M. Mitchell (Jaycor Corporation).

Hamel, P.B. 1992. Land Manager's Guide to the Birds of the South, The Nature Conservancy, Southeastern Region, Chapel Hill, N. C., p 437.

Hamel, P. B., et al. 1994. A Land Manager's Guide to Point Counts of Birds in the Southeast, unpublished, p. 90.

Harvey, M. J. 1992. Bats of the Eastern United States, Arkansas Game and Fish Commission, U.S. Fish and Wildlife Service and Tennessee Technological University, Cookville, Tenn.

Heyer, W. R., et al., eds. 1994. Measuring and Monitoring Biological Diversity: Standard Methods for Amphibians, Smithsonian Institution Press, Washington, D. C., and London, p. 364.

Howell, J. C. 1958. Long-Range Ecological Study of the Oak Ridge Area, I. Observations on the Summer Birds in Melton Valley, Oak Ridge National Laboratory, Oak Ridge, Tenn., p. 34.

Howell, J. C., and P. B. Dunaway 1958. Long-Term Ecological Study of the Oak Ridge Area: II. Observations on the Mammals with Special Reference to Melton Valley, Oak Ridge National Laboratory, Oak Ridge, Tenn., p. 22.

Johnson, R. M. 1964. Herptafauna of the Oak Ridge Area, ORNL-3653, Oak Ridge National Laboratory, Oak Ridge, Tenn., p. 28.

Karns, D. R. 1986. Field Herpetology: Methods for the Study of Amphibians and Reptiles in Minnesota, University of Minnesota, Minneapolis, Minn., p. 88.

Kitchings, J. T., and L. K. Mann 1976. A Description of the Terrestrial Ecology of the Oak Ridge Environmental Research Park, ORNL/TM-5073, Oak Ridge National Laboratory, Oak Ridge, Tenn., p. 58.

Klein, J. A. 1989. A Checklist of Reptiles and Amphibians on the Department of Energy Oak Ridge Reservation, Anderson and Roane Counties, Tennessee, J. Tenn. Acad. Sci., 64, pp. 228-230.

Klein, J. A. (Oak Ridge National Laboratory) January 10, 1995. Personal communication with E. R. Vail (Jaycor Corporation) and J. M. Mitchell (Jaycor Corporation).

Kroodsma, R. L. 1987. Resource Management Plan for the Oak Ridge Reservation, Volume 24: Threatened and Endangered Animal Species, ORNL/ESH-1/V24, Oak Ridge National Laboratory, Oak Ridge, Tenn., p. 24.

Kroodsma, R. L. 1993. Threatened and Endangered Animals at the Oak Ridge National Laboratory Developed Areas, Oak Ridge National Laboratory, Oak Ridge, Tenn., p. 11.

Kroodsma, R. L. 1995. Personal communication with J. M. Mitchell (Jaycor Corporation), May 18.

Martin Marietta Energy Systems, Inc. 1994. Environmentally Sensitive Areas Surveys Program, Threatened and Endangered Species Survey Progress Report, ES/ER/TM-130, Martin Marietta Energy Systems, Inc., Oak Ridge, Tenn.

Robinson, J. C. 1990. An Annotated Checklist of the Birds of Tennessee, University of Tennessee Press, Knoxville, Tenn., p. 274.

TWRA (Tennessee Wildlife Resources Agency 1994a. "Endangered or Threatened Species," Tennessee Wildlife Resources Commission Proclamation 94-17, as amended on September 27, 1994, Nashville, Tenn.

TWRA 1994b. "Wildlife in Need of Management," Tennessee Wildlife Resources Commission Proclamation 94-16, as amended on September 27, 1994, Nashville, Tenn. 
Appendix A

TWRA 1994A AND TWRA 1994B:

SPECIES LISTED AS THREATENED,

ENDANGERED, OR IN NEED OF MANAGEMENT 



\section{A-3}

SUMMARY OF PROCLAMATION 94-16

Robert M. Hather, Endangered Species Coordinator

Tennessee Wildlife Resources Agency

September 27, 1994 (approved by Commission today)

Proc. $94-16$ repeals and supplants Proc. $88-29$ by deleting all previously-isted 'Wildlife in Need of Management" and replacing them. A total of 36 changes are shown below.

\begin{tabular}{|c|c|c|c|c|c|c|}
\hline No. By: & Fish & Amphi & Roptile & Birds & Mam & Tot \\
\hline $\begin{array}{l}\text { Former } \\
\text { Sp. }\end{array}$ & 38 & 6 & 6 & 14 & 13 & $\pi$ \\
\hline $\begin{array}{l}\text { Pro. } \\
\text { posed }\end{array}$ & 40 & 11 & 5 & 19 & 14 & 89 \\
\hline Rotained & 36 & 5 & 4 & 9 & 13 & 67 \\
\hline Dolisted & 0 & $\begin{array}{c}1 \\
\text { Groen } \\
\text { Salam. }\end{array}$ & $\begin{array}{l}2 \\
\text { Cumb. } \\
\text { slider, } \\
\text { 6-Linod } \\
\text { Racer? }\end{array}$ & $\begin{array}{l}4 \\
\text { Red-sh'ldered HK; } \\
\text { Black Vulture; } \\
\text { Reothoeded } \\
\text { Woodpecker, } \\
\text { Bl-Cr Night Heron }\end{array}$ & 0 & 7 \\
\hline $\begin{array}{l}\text { Uplisted } \\
\text { (to T or } \\
\text { E) }\end{array}$ & $\begin{array}{l}2 \\
\text { Bluemask: } \\
\text { Palezono }\end{array}$ & 0 & 0 & $\stackrel{1}{1}$ Lark Sparrow & 0 & 3 \\
\hline $\begin{array}{l}\text { Downilst } \\
\text { (to this } \\
\text { level) }\end{array}$ & 0 & 0 & 0 & $\begin{array}{l}5 \\
\text { Shapp-shimned Hik } \\
\text { Coopers Hawik } \\
\text { Grasunopper Sp. } \\
\text { Northern Harrier, } \\
\text { Miss. Kite }\end{array}$ & 0 & 5 \\
\hline $\begin{array}{l}\text { Now } \\
\text { Llettings }\end{array}$ & $\begin{array}{l}4 \\
\text { Smoky Dace, } \\
\text { Firebelly } \\
\text { Darter, } \\
\text { Bigmouth } \\
\text { Shiner, } \\
\text { N Madtom }\end{array}$ & $\begin{array}{c}6 \\
\text { Soopage } \\
\text { Salam. } \\
\text { Brktoilly, } \\
\text { Salam., } \\
\text { Pyomy S, } \\
\text { Junaluska, } \\
\text { Wollers S.; } \\
\text { Wehria's }\end{array}$ & $\begin{array}{c}1 \\
\text { Coal } \\
\text { Skink }\end{array}$ & $\begin{array}{l}5 \\
\text { N. Saw-whet Ow' } \\
\text { Ollve-sided. } \\
\text { Fiycatcher } \\
\text { Litte Blus Heron } \\
\text { Snowy Eoret } \\
\text { King Rail }\end{array}$ & $\begin{array}{r}1 \\
\text { Rock } \\
\text { Vole }\end{array}$ & 17 \\
\hline $\begin{array}{l}\text { Name } \\
\text { Change }\end{array}$ & 4 & 0 & 0 & 0 & 0 & 4 \\
\hline
\end{tabular}

RMH:bno1065/datahwildife/hatcher/list/94-16Sum.ip 
TENNESSEE WILDLIFE RESOURCES COMMISSION PROCLAMATION

WILDLIFE IN NEED OF MANAGEMENT

Pursuant to the authority granted by Tennessee Code Annotated. Sections 70-8104 and 70-8-107, the Tennessee Wildife Resources Commission does hereby declare the following species to be wildife in need of management.

SECTION I. SPECIES

\section{ESH}

\begin{tabular}{|c|c|}
\hline Alabama Shad & Alosa alabamae \\
\hline Crystal Darter & Ammocrypta asprella \\
\hline Naked Sand Darter & A. beani \\
\hline Scaly Sand Darter & A. vivax \\
\hline Highfin Carpsucker & Carpiodes velifer \\
\hline Smoky Dace & Clnostomus sp. Af. tunduloides \\
\hline Sharphead Darter & Etheostome acuticeps \\
\hline Emeraid Darter & E bailey \\
\hline Teardrop Darter & E bartouri \\
\hline Splendid Darter & E. barrenense (Ulocentra, sp.) \\
\hline Orangefin Darter. & E bellum \\
\hline Asthy Darter & E choreum \\
\hline Redband Darter & E luteovinctum \\
\hline Finescale Darter & E microlepidum \\
\hline Firebelllv Darter (=Red Snubnose Darter & E. pynhogaster (=E. (Ulocentra)] \\
\hline Arrow Darter & E sagitia \\
\hline Striated (Duckriver Barcheek) Darter & E. striatulum \\
\hline Tippecanoe Darter & E. tippecanoe \\
\hline
\end{tabular}

P200. 94-16 


\section{A-5}

\begin{tabular}{|c|c|}
\hline Tuscumbia Darter & E. tuscumbia \\
\hline Golden Topminnow & Fundulus chrysotus \\
\hline Flame Chub & Hemitremia flammea \\
\hline Plains Minnow & Hybognathus placitus \\
\hline Southem Brook Lamprey & lehthyomyzon gagai \\
\hline Silver Lamprey & 1. uniarspis \\
\hline Lined Chub & Notropis lineapunctatus \\
\hline Harelip Sucker & Lagoctilla lacera \\
\hline Alligator Gar & Lepisosteus spatula \\
\hline Sturgeon Chub & Mecrohybopsis gelida \\
\hline Sidxlefin Chub & M. mooks \\
\hline Blackfin Sucker & Moxostoma atripinne \\
\hline Bigmouth Shiner & Notropis dorsalis \\
\hline Roseface Shiner & N. r. rubellus \\
\hline Bedrock Shiner & N. rupestris \\
\hline Northem Madtom & Notunis̄e etigmosus \\
\hline Tangerine Darter & Porcina aurantiace \\
\hline Blotchside Logperch & P. burtont \\
\hline Blackfin Darter & P. (Odontophilus) sp. \\
\hline Slendertiead Darter & P. phoxocophala \\
\hline Tennessee (= Mountain Redbelly) Dace & Phoxinus tonnesseensis \\
\hline Southem Cavefish & Typhlichthys subterranous \\
\hline
\end{tabular}

\section{AMPHAIANS.}

\begin{tabular}{|l|l|}
\hline Mole Salamander & Ambystoma talpoideum \\
\hline Heilbender & Cryptobranctus a. alloganionsis \\
\hline
\end{tabular}




\begin{tabular}{|l|l|}
\hline Seepage Salamander & Desmognathus aeneus \\
\hline Black-bellied Salamander & D. quadramaculatus \\
\hline Black Mountain Dusky Salamander & D. welteri \\
\hline Pygmy Salamander & D. wright \\
\hline Junaluska Salamander & Euncea junaluska \\
\hline Four Toed Salamander & Hemidactylium scutatum \\
\hline Barking Treefrog & Hyla gratiosa \\
\hline Wellers Salamander & Plethodon welleri \\
\hline Wehrie's Salamander & P. wohriei \\
\hline
\end{tabular}

\section{REPTIIES}

\begin{tabular}{|l|l|}
\hline Green Anole & Anolis carolinensis \\
\hline Coal Skink & Eumeces anthracinus \\
\hline Aligator Snapping Turtle. & Macroclemys temmincti \\
\hline Green Water Snake & Nerodia (Natrix) cydiopion \\
\hline Eastem Slender Glass Lizard & Ophisauns attenuatus longicaudus \\
\hline
\end{tabular}

\section{BIRDS}

\begin{tabular}{|l|l|}
\hline Sharp-shinned Hawk & Accipiter striatus \\
\hline Coopers Hawk & A. coopert \\
\hline Northem Saw-Whet Ow & Aegolius acadicus \\
\hline Grasshopper Sparrow & Ammodramus savannarum \\
\hline Anhinga & Anhinga anhinga \\
\hline Great Egret & Cesmerodius albus \\
\hline Northem Harrier & Circus Cyaneus \\
\hline Oltve-sided Flycatcher & Contopus borealis \\
\hline Little Blue Heron & Egretta caerulea \\
\hline
\end{tabular}

Proc. 94-16 


\begin{tabular}{|l|l|}
\hline Snowy Egret & E thula \\
\hline Sandhill Crane & Grus candensis \\
\hline Mississiopi Kite & letinia mississiopiensis \\
\hline Least Bittem & Ixobrychus exilis \\
\hline Swainson's Wartler & Limnothlypis swainsonii \\
\hline Double-crested Comorant & Phalacrocorax auritus \\
\hline Vesper Sparrow & Pooecetes gramineus \\
\hline King Rail & Rallus elegans \\
\hline Yellow-bellied Sapsucker & Sphyrapicus varius \\
\hline Common Bam-Owl & Tyto alba \\
\hline
\end{tabular}

\section{MAMMALS}

\begin{tabular}{|l|l|}
\hline Star-nosed Mole & Condylura cristata \\
\hline Yellownose (=Rock) Vole & Microtus chrotorminus \\
\hline Woodland Jumping Mouse & Napaeozapus insignis \\
\hline Small-footed Bat & Myotis leibii \\
\hline Eastem Woodrat & Neotoma foridana \\
\hline Hairy-tailed Mole & Parascalops breweri \\
\hline Rafineque's (=Eastem) Big-eared Bat & Plecotus rafinesquii \\
\hline Masked Shrew & Sorex cinoreus \\
\hline Longtail Shrew & S. dispar \\
\hline Smoky Shrew & S. fumeus \\
\hline Southeastem Shrew & S. longirostris \\
\hline Water Shrew & S. palustris \\
\hline Southem Bog Lemming & Synaptomys cooperi \\
\hline Meadmw Jumping Mouse & Zapus hudsonius \\
\hline
\end{tabular}




\section{SUMMARY OF PROCLAMATION 94-17 \\ Rober M. Hatcher, Endangered Species Coordinator \\ Tennessee Wildlife Resources Agency \\ September 27, 1994 (Approved by Commission today)}

Proc. 94-17 repeals and supplants Proc. 86-30 by deleting all previousty-listed "Endangered \& Threatened Wildlife" and replaces them. A total of 52 changes are made. Hightights inctude:

- revision of 11 species' names due to official nationwide name changes,

- addition of 15 new mollusk species due to prior Federal listings,

- delisting of Chittenango ovate amber snail due to change in its taxonomic ctassification.

- uplisting trom "In Need of Management" or T to $E$ status the: bluemask darter and palezone shiner, and duskytail darter,

- addition of 6 fish species due to prior Federal listing (4) and expert recommendations.

- downlisting of Mississidpi Kite from Endangered to "In Need of Management".

- cownlisting from Threatened to "In Need of Management" the: Sharp-shinned Hawk, Coopers Hawk, Grassnopper Sparrow, and Northem Harrier, and

- downilsting from Endangered to Threatened the: the Batd Eagte. Golden Eagle. Common Raven, and Osprey.

- addition of the Red Wolf as Endangered, as limited to its experimental range in GSMNP

Changes by wildlife class are:

\begin{tabular}{|c|c|c|c|c|c|c|c|c|c|c|c|c|c|c|c|c|}
\hline & \multicolumn{2}{|c|}{ Mollusk } & \multicolumn{2}{|c|}{ Fish } & \multicolumn{2}{|c|}{ Amphib } & \multicolumn{2}{|c|}{ Reptile } & \multicolumn{2}{|c|}{ Blinds } & \multicolumn{2}{|c|}{ Mam. } & \multicolumn{2}{|c|}{ Crun } & \multicolumn{2}{|c|}{ Total } \\
\hline Nos. By: & E & $\mathbf{T}$ & $\mathbf{E}$ & $\mathbf{T}$ & $\mathbf{E}$ & $\mathbf{T}$ & $E$ & $\mathbf{T}$ & $E$ & $\mathbf{T}$ & $E$ & $\mathbf{T}$ & E & $\mathbf{T}$ & $E$ & $T$ \\
\hline Former & 24 & 1 & 10 & 14 & 0 & 1 & 0 & 3 & 9 & 5 & 4 & 1 & .1 & 0 & 48 & 25 \\
\hline Proposed & 37 & 2 & 17 & 15 & 0 & 1 & $\mathbf{0}$ & 3 & 4 & 6 & 5 & 1 & 1 & 0 & 64 & 28 \\
\hline Retained & 24 & 0 & 10 & 13 & & 1 & & 3 & 4 & 1 & 4 & 1 &. .1 & & 43 & 19 \\
\hline Delleted & 0 & 9 & 0 & 0 & & 0 & & 0 & 0 & 0 & 0 & 0 & 0 & & 0 & 1 \\
\hline Downilisted & 0 & 0 & 0 & 0 & & 0 & & 0 & 5 & 8 & 0 & 0 & 0 & & 5 & 8 \\
\hline Upllatede & 0 & 0 & 3 & 1 & & 0 & & 0 & 0 & 1 & 0. & 0 & 0 & & 3 & 2 \\
\hline Now Ustings - & 13 & 2 & 4 & 2 & & 0 & & 0 & 0 & 0 & 1 & 0 & 0 & & 18 & 4 \\
\hline Namo Chang & 8 & 0 & 0 & 1 & & 0 & & 1 & 1 & 0 & 0 & 0 & 0 & & 9 & 2 \\
\hline Fed. Status & 36 & $\begin{array}{l}1 \\
2- \\
c_{1}\end{array}$ & 10 & 3 & 0 & $\begin{array}{l}0 \\
1- \\
02\end{array}$ & 0 & $\begin{array}{l}0 \\
2 . \\
C 2\end{array}$ & 4 & 1 & 4 & 0 & 1 & 0 & $\begin{array}{l}55 \\
2- \\
c 1\end{array}$ & $\begin{array}{l}7 \\
3- \\
02\end{array}$ \\
\hline
\end{tabular}

Uplistings and cownistungs may be counted twice, one at $T$ status and one at $E$ status; or they may invoive similar pairing (uptisting or downtisting ) with "In Noed of Mgt." status. 
Pursuant to the authozity granted by Tennessee Code Annotated. Secticns 70-a-i05 and 70-9-:07, the Tennessee wildlife Resources Comassion does hereby declare the following spectes to be endangered or threacened subject to the regulations as herein provided.

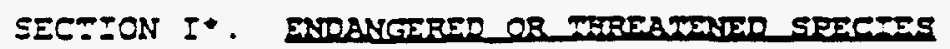

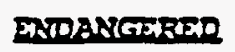

vorrtages

Comeros Name

Selentific Name

\begin{tabular}{|c|c|c|}
\hline Appalacisian elktoe & Alasmidonca raveneliana & $C:$ \\
\hline Birdwing pearly mussel & $\begin{array}{l}\text { Conradilla caelata (-Limiox } \\
\text { rimosus) }\end{array}$ & E \\
\hline Fanshell Mussel & Cyprogania stegaria (-irrorata) & $\Sigma$ \\
\hline Dromedary pearly mussel & Dromus dromas & $\Sigma$ \\
\hline Yellow-blossom pearly mussel & $\begin{array}{l}\text { Epiablasma (-Dysnomia) } \\
\text { florentina florentina }\end{array}$ & $\boldsymbol{E}$ \\
\hline Upland combshel1 & E. metastriata & $\Sigma$ \\
\hline Southern acornshell & E. ochealoogensis & $\Sigma$ \\
\hline Green-blossom pearly mussel & $\begin{array}{l}\text { E. (-Dysnomia) tozulosa } \\
\text { gubernaculum }\end{array}$ & $\mathbf{E}$ \\
\hline Iuberauled-blossom pearly mussed & $\begin{array}{l}\text { E. (-Dysnomia) torulosa } \\
\text { toralosa }\end{array}$ & $E$ \\
\hline Turgid-blossom pearly mussel & E. (-Dysnomia) turgidula & $\varepsilon$ \\
\hline Tan Iifzleshell & E. (-Dysnomia) walkeri & $\Sigma$ \\
\hline Purpie Cat's Paw Pearlymussel & $\begin{array}{l}\text { E. (-Dyanomia) obliquata } \\
\text { abliquaca (-E. sulcata sulcata) }\end{array}$ & $-\Sigma$ \\
\hline Eine-rayed pigtoe & Eusconaia cuneolus & $\varepsilon$ \\
\hline shiny pigtoe & F. cor (-edgariana) & $\mathbf{E}$ \\
\hline Cracking pearly uussel & Eemistena (-Lastena) laca & $E$ \\
\hline Pink mucket pearly mussel & Lampsilis abrupta (-orbiculatal & $\Xi$ \\
\hline
\end{tabular}

Proc. 94-17 
EI5P

\section{MIDANGIRED}

Common Name

Seientile Name Fad*t

\begin{tabular}{|c|c|c|}
\hline Lake sturgeon & Acipenser Iulvescens & $\mathrm{C2}$ \\
\hline Tuckasegee Darrer & Etheostoma blenniodes gutselii & -- \\
\hline Bluemask (-jewel) Darzer & E. (Doration) sp & E \\
\hline Duskycail Darcer & E. (-Catorotus sp.) & $\mathbf{E}$ \\
\hline Crown Darter & E (=Catonotus sp.) corona & - \\
\hline Barzens Darter & E. (-Catonotus sp.) Forbesi & -- \\
\hline Egg-mimic Darter & E. (=Catonotus) pseudoralacur- & $\boldsymbol{E}$ \\
\hline Boulder Dafzer & E. (Nothonotus) wapiei & $\mathbf{E}$ \\
\hline Spoteis Chu & Cyprinella (-Hybopsis) monacha & I \\
\hline Blue Shiner & $\begin{array}{l}\text { Cyprinella (-Notropis) caerulea } \\
\text { (-caeruleus) }\end{array}$ & $T$ \\
\hline Palezone Shiner & Notropis sp. (CE. N. procre) & $\mathbf{E}$ \\
\hline Smoky Madtom & Noturys baileyi & $\mathbf{E}$ \\
\hline Yellowtin Madeor & Noturus Flavipinnis & $\mathbf{T}$ \\
\hline Pygmy Madtom & Notyrus stanauli & 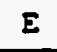 \\
\hline Amber Darter & Percina antesella & $\boldsymbol{E}$ \\
\hline Conasauga (=Rerzeulacel Logperch & R. fenkinsi & $E$ \\
\hline Palldd stuzgeon & scaphl rhymerus albus & $\mathbf{E}$ \\
\hline
\end{tabular}

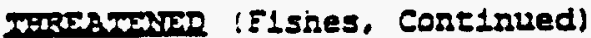

Cormon Name

Badentetle Namo

Fed**

\begin{tabular}{|l|l|c|}
\hline Western Sand Sarter & Ameocpta clara & -- \\
\hline Blue Sucker & Cycleptus elongatus & C2 \\
\hline Slender Chub & Erimystax (-Hybopsis) cahni & $\mathrm{T}$ \\
\hline Slackwater Darter & Etheostowa boschungi & $\mathrm{I}$ \\
\hline Coldwater Darcer & E. ditrema & $\mathrm{C2}$ \\
\hline Trispot Darcer & E. Erlsella & $\mathrm{C2}$ \\
\hline
\end{tabular}

Proc. 94-17 


\begin{tabular}{|c|c|c|}
\hline Alabama lamp pearly mussel & L. vizescens & $\Sigma$ \\
\hline Coosa mocsasinshell & Medionidus parvulus & E \\
\hline RLIgg pink mussel & Obovaria resusa & $\Sigma$ \\
\hline Ilttle-wing pearly mussel & Pegias fabula & E \\
\hline White warcy-back pearly mussel & Plechobasus cicatricosus & $\varepsilon$ \\
\hline $\begin{array}{l}\text { Orange-footed (-pinapleback) } \\
\text { peariy mussel }\end{array}$ & P. cooperianus & $\Xi$ \\
\hline Clubshell & Pleurobeme clava & $\Sigma$ \\
\hline Southerr clubsholl & P. decisum & $\mathbf{\varepsilon}$ \\
\hline Southern pigtoe & P. georgianum & $\Sigma$ \\
\hline $\begin{array}{l}\text { Cumberland pigroe (-Cumberland } \\
\text { plgroe mussel) }\end{array}$ & P. gibberm & $\varepsilon$ \\
\hline Ovate elubshell & P. parovatum & E \\
\hline Rough pigroe pearly mussel & P. plenum & $\mathbf{E}$ \\
\hline Iriangular kidneyshill & Peychobranchus greeni & E \\
\hline $\begin{array}{l}\text { Cumberland monkeyface pearly } \\
\text { massel }\end{array}$ & Quadrala intermedia & $\mathbf{E}$ \\
\hline Winged mapleleaf mussel & Q. Eragosa & $\mathbf{E}$ \\
\hline $\begin{array}{l}\text { Appaiachian morkeytace pearly } \\
\text { mussel }\end{array}$ & 0. sparsa & $\mathbf{E}$ \\
\hline Pale 11111pue peariy mensel & $\begin{array}{l}\text { Toxolamin (-Carunculina) } \\
\text { cyllndrelle }\end{array}$ & $\mathbf{E}$ \\
\hline Cumberland bean pearly muncel & visloaa (omeromyal erabal1s & $\mathbf{E}$ \\
\hline Painted snake coiled forest snail & Angrispira pieta & $\mathbf{T}$ \\
\hline Anthony's siversnail & Athearnia anchonyi & $\mathbf{E}$ \\
\hline Royal Snail & $\begin{array}{l}\text { Pyroulopsis (=Marstonia) } \\
\text { ogmorhaphe }\end{array}$ & $\mathbf{E}$ \\
\hline
\end{tabular}

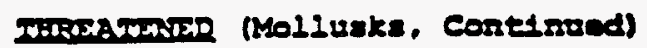

Cownon Name

getentele Nam

Fod

\begin{tabular}{|l|l|c|}
\hline Rlabama moccasinshell & Modionidus acreissimus & T \\
\hline Flno-11ned pocketbook & Lampsills alt1113 & T \\
\hline
\end{tabular}

Proe. 94-17 
A-12

\begin{tabular}{|c|c|c|}
\hline Coppercheek Darter & E. aquali (CF. E.maculatum) & C2 \\
\hline Holliday (-Ellijay) Darter & E. (-Ulacentral sp̣. & -- \\
\hline Barrens Topminnow & $\begin{array}{l}\text { Fundulus julisia (ct. F. } \\
\text { albolineatus) }\end{array}$ & $\mathrm{C2}$ \\
\hline S11verjaw M1nrow & Norropis (-Ericymba) buccata & -- \\
\hline Frecklebelly Madtom & Norurus muritus & $\mathrm{C2}$ \\
\hline Duck River Saddled Madtom & Noturus sp. (-elegans) & $\mathrm{C2}$ \\
\hline Longhead Darter & Percina macrocephala & $\mathrm{C2}$ \\
\hline Snall Dareer & P. canasi & $T$ \\
\hline Blackslde Dace & Phoxinys cumberlandensis & $T$ \\
\hline
\end{tabular}

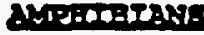

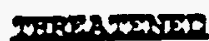

Cer..non Name

sotantifle Nam

Fed

Tennessee Cave Salamander

Gyrinophilus palleucus

C2

Bapontas:

\section{Toisosatomithe}

Cominor Name

Sedentifle Nom

Fod t*

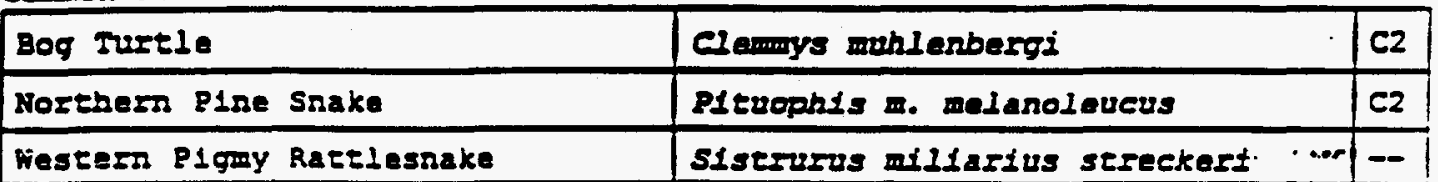

mospa

AIMASGMEXP

Ce....on Nama

sedentele Nam

\begin{tabular}{|c|c|c|}
\hline Cc.....on Nama & conentese Nan & adet \\
\hline Bacbman's Sparrow & Atmophila aeseivalis & $\mathrm{C2}$ \\
\hline Peregrine Falcon & Falco peregrinus & $\mathbf{T}$ \\
\hline Red-cockaded Woodpecker & Plcoides (-Dendrocopos) borealis & $\mathbf{E}$ \\
\hline Least Tern & Sterna antIIlarum & $\varepsilon$ \\
\hline
\end{tabular}

Proe. 94-17 
IFrsatrugen (B1rds, Continued)

Comon Namo

Seientelle Name

Fed"

\begin{tabular}{|l|l|c|}
\hline Golden Eagle & Aquila chrysaeros & -- \\
\hline Lark Sparfow & Chondestes grammacus & -- \\
\hline Common Raven & Corvus corax & -- \\
\hline Bald Eagle & Haliaeecus leucocephalus & T \\
\hline Osprey & Pandion haliaetus & -- \\
\hline BewiCX's Wren & Mryomanes bewickii & C2 \\
\hline
\end{tabular}

MaMatas

MNDANGHRER

Comon Namo

Seiantifle Namo

Fod:-

Red Molf (Where listed as

"Experimental population" in

Tennessee)

Eastern Cougar

Carolina Northern Elying Squirrel

\begin{tabular}{|l|c|}
\hline Canis surus & E \\
\hline Pelis concolor cougar & E \\
\hline Glaucomys sabrinus coloratus & E \\
\hline Myotis grisescens & E \\
\hline M. sodalis & E \\
\hline
\end{tabular}

Indlana Myotis

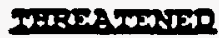

Cormon Namo

Betentele Name

Rlver otter (Excepr west

of Kentucky \& Plckwick Lakes!

Iutra canadensis

Fed*

\section{miogeracosans}

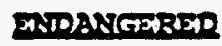

Comon Nama

getanet fle Nima

Eedw

Nashrille Crayfish Orconectes shoupi

- Fed: $E$ = Fed. End., I = Fed. Threat., CI = Candidate for I1kely Federal Listing; C2 = Candidate for Possibie Fed. Ilsting.

Proc. $94-17$ 


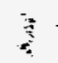

Appendix B

TWENTY-NINE NONTARGETED SPECIES 

Birds

Northern saw-whet owl

Anhinga

Golden eagle

Lark sparrow

Common raven

Mississippi kite

Bewick's wren

Swainson's warbler

Bachman's sparrow

Peregrine falcon

Red-cockaded woodpecker

Least tern

Reptiles and Amphibians

Seepage salamander

Black-bellied salamander

Pygmy salamander

Weller's salamander

Junaluska salamander

Barking tree frog

Alligator snapping turtle

Wehrle's salamander

Western pygmy rattlesnake

\section{Mammals}

Star-nosed mole

Hairy-tailed mole

Long-tailed shrew

Red wolf

Eastern cougar

Carolina northern flying squirrel

River otter 
Appendix C

NONAVIAN SITE LOCATIONS ON THE ORR 



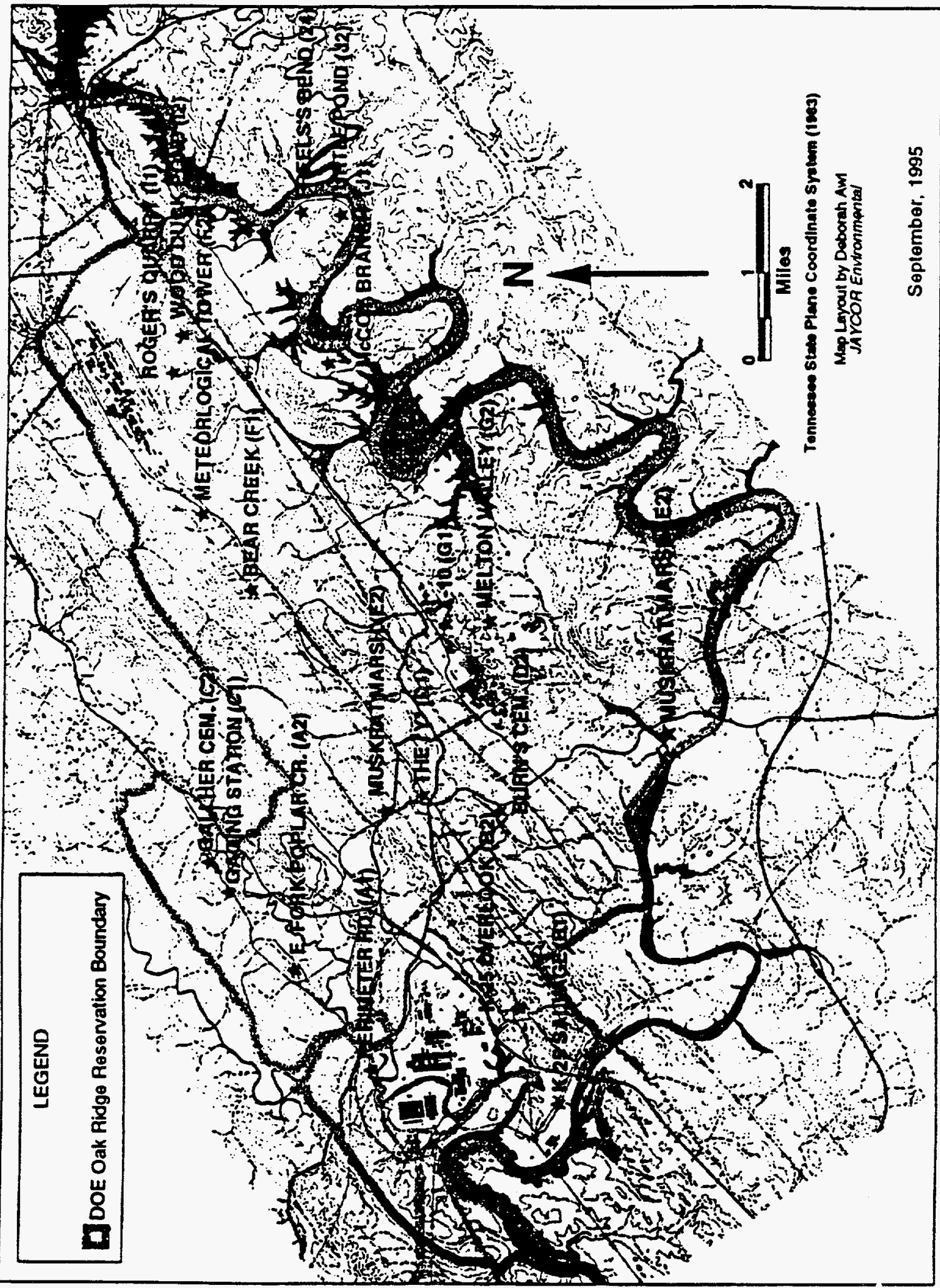


Appendix D

SITE MAPS FOR PITFALL AND SHERMAN TRAP PLACEMENT ON THE ORR, FEBRUARY-SEPTEMBER 1995 

D-3

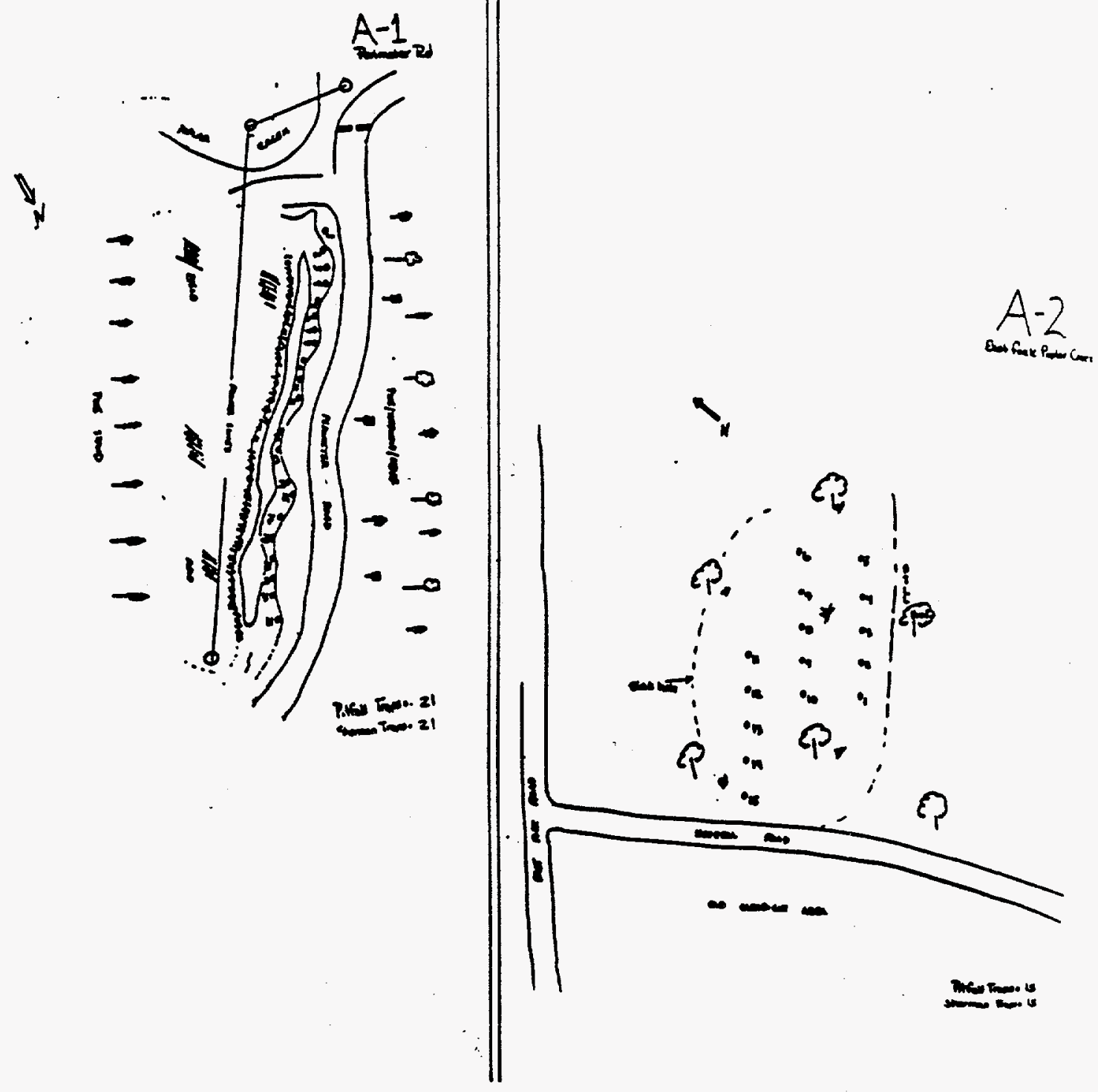




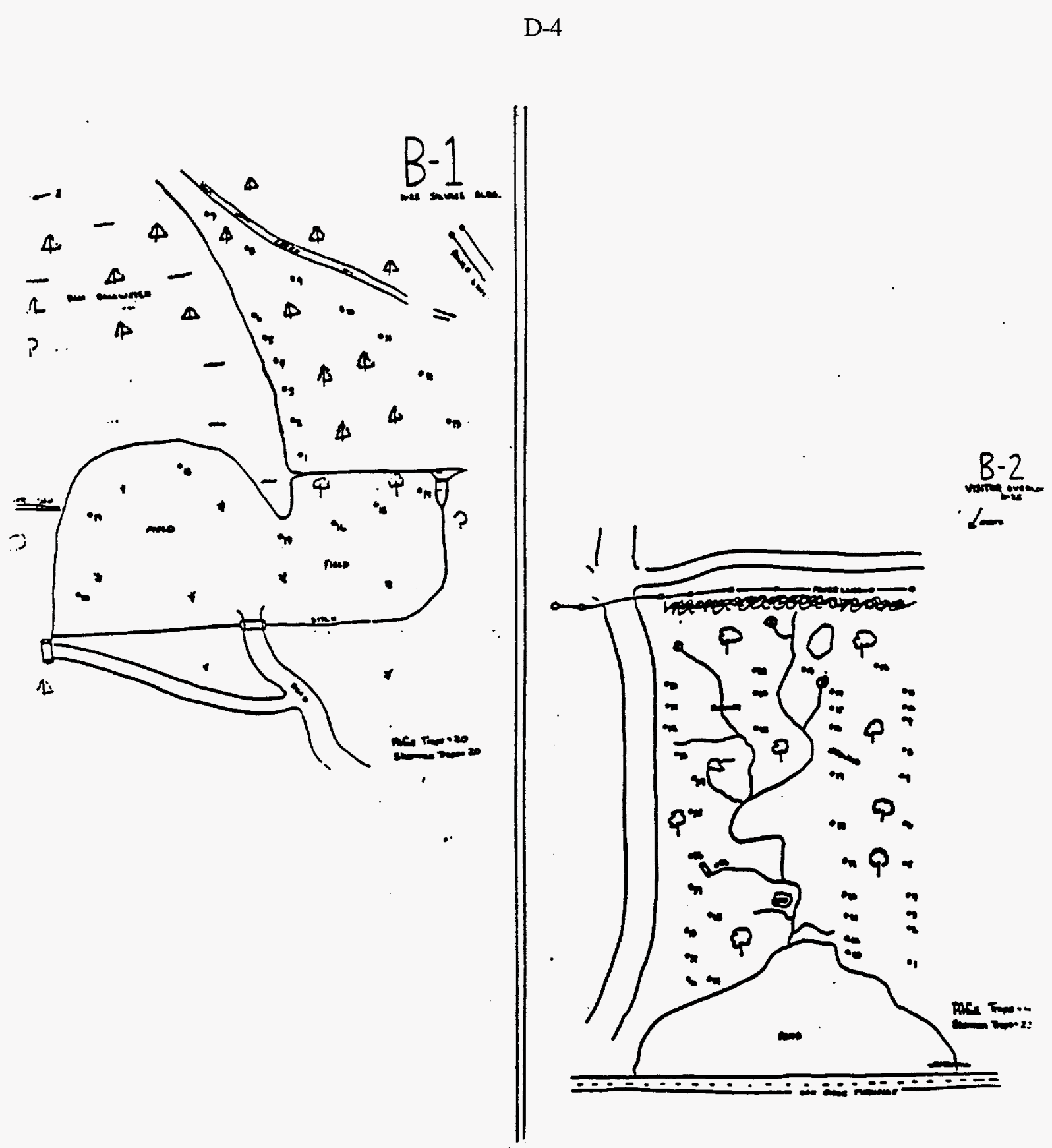




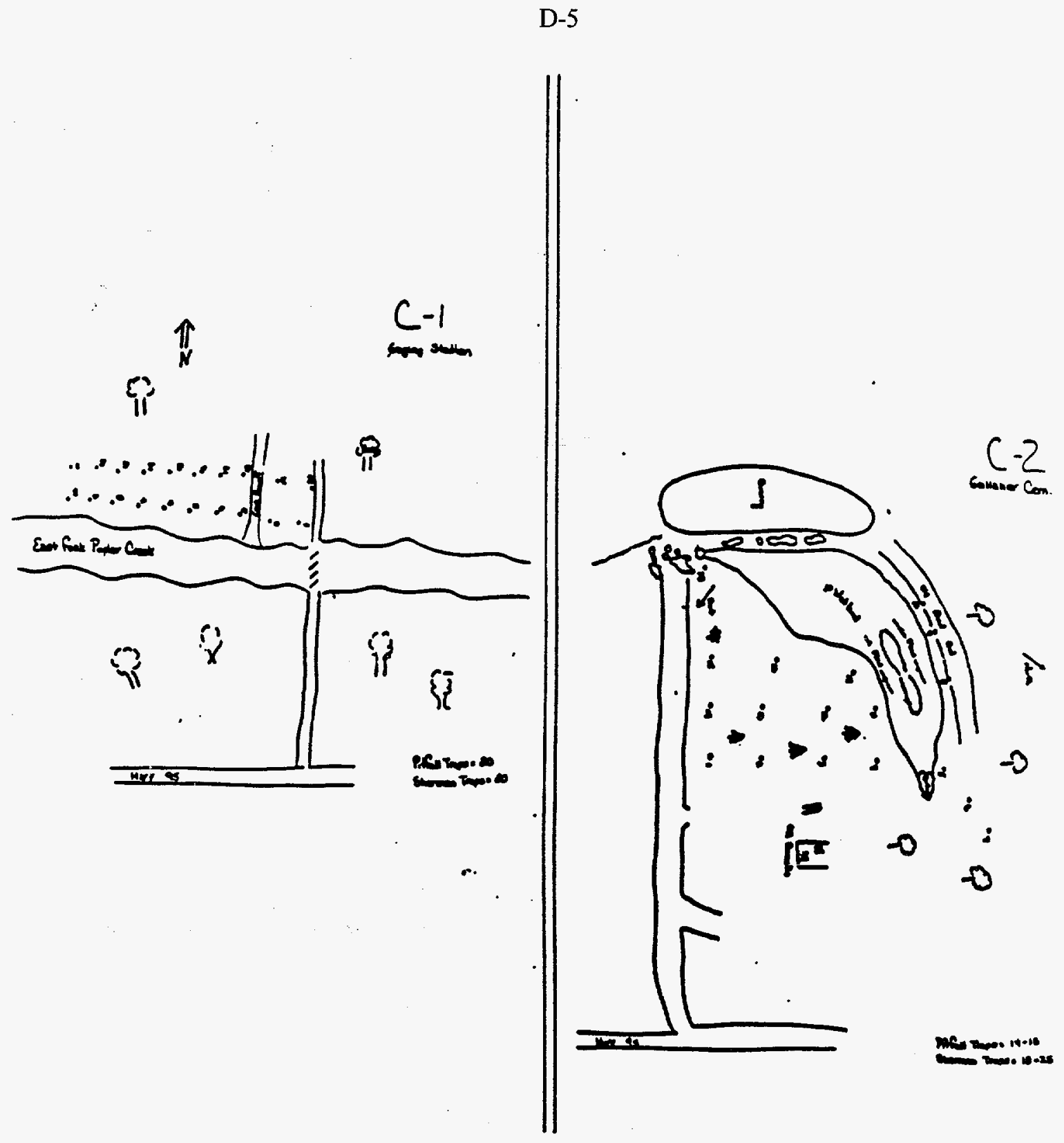


D-6

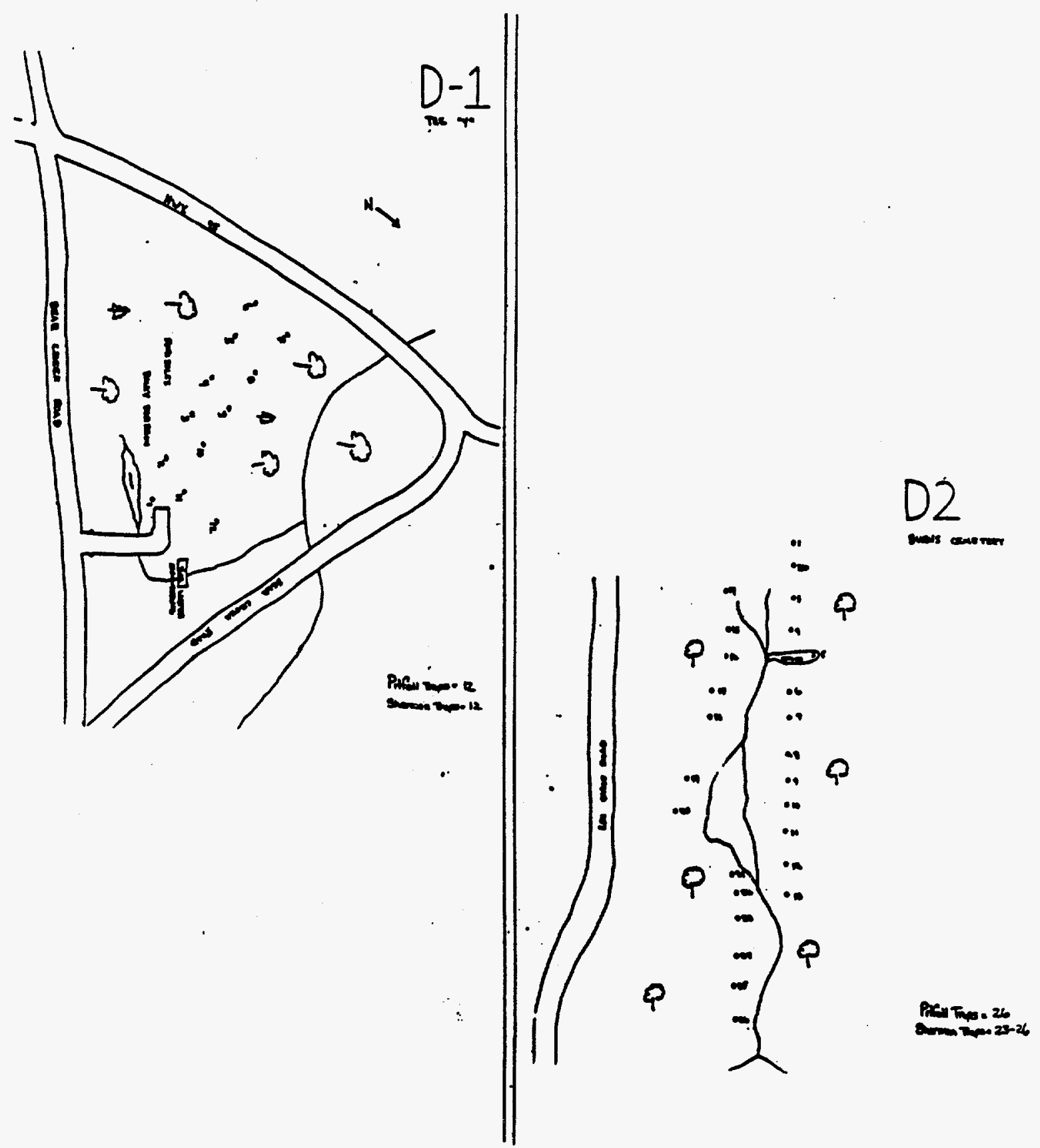


D-7
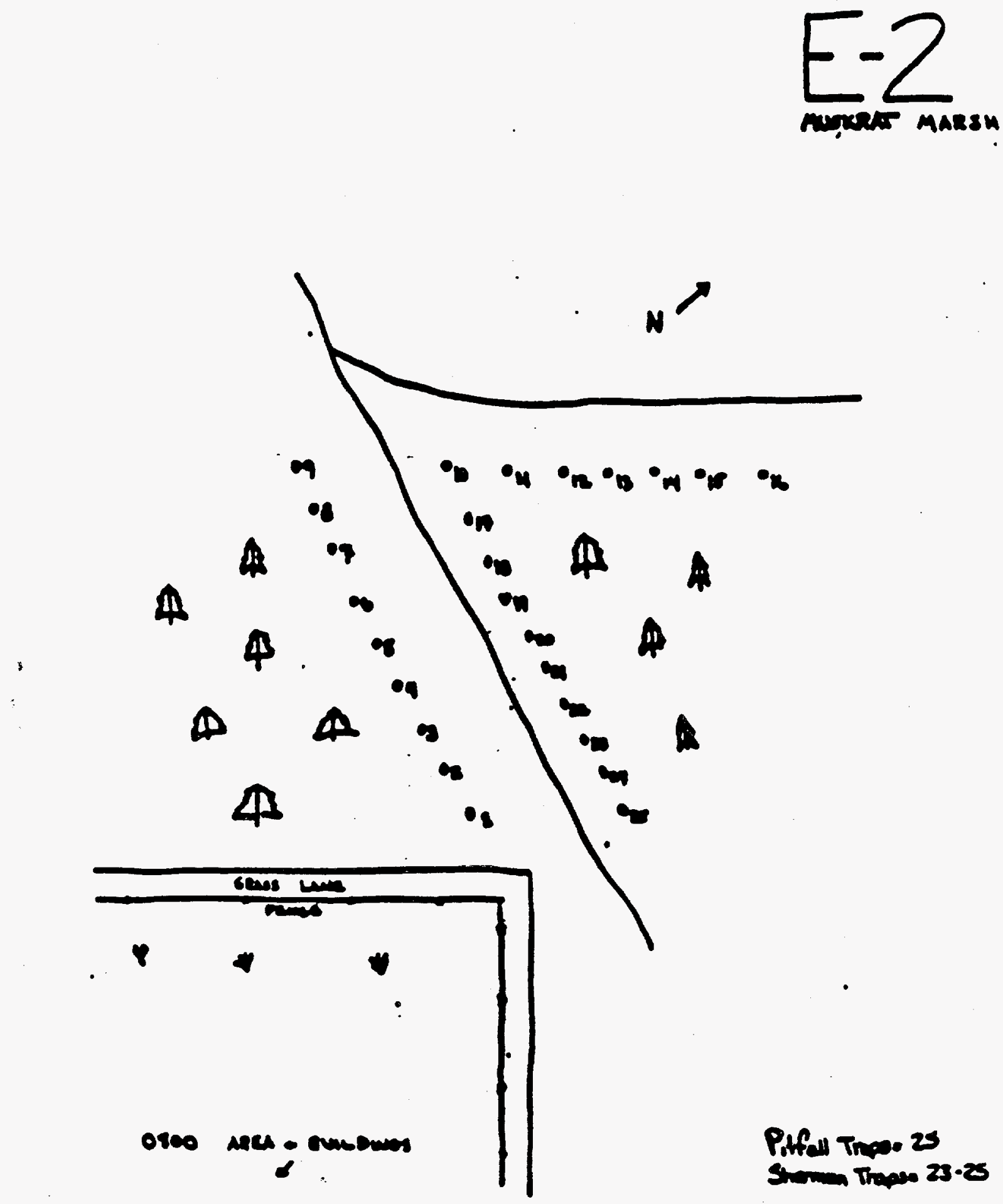


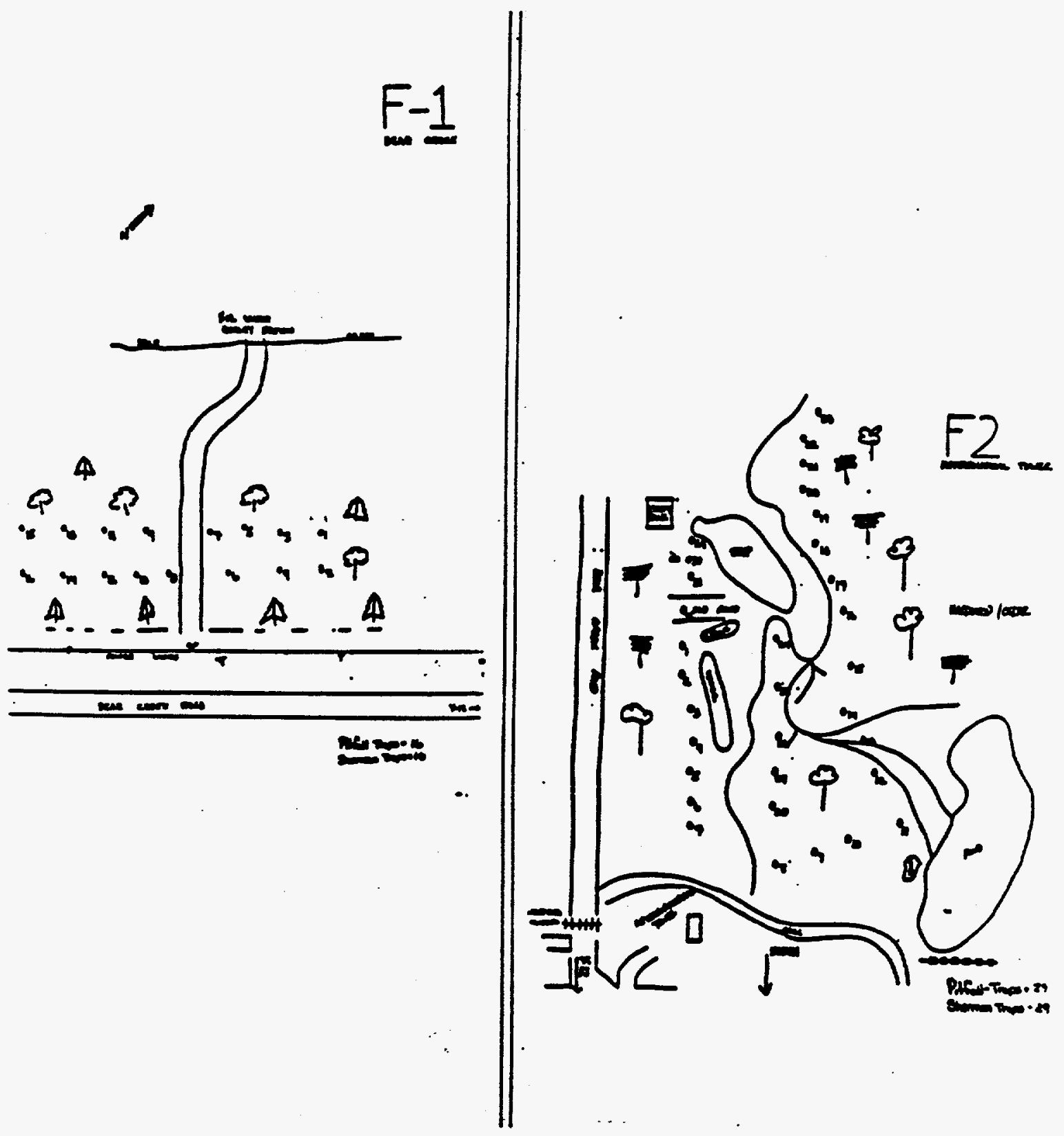




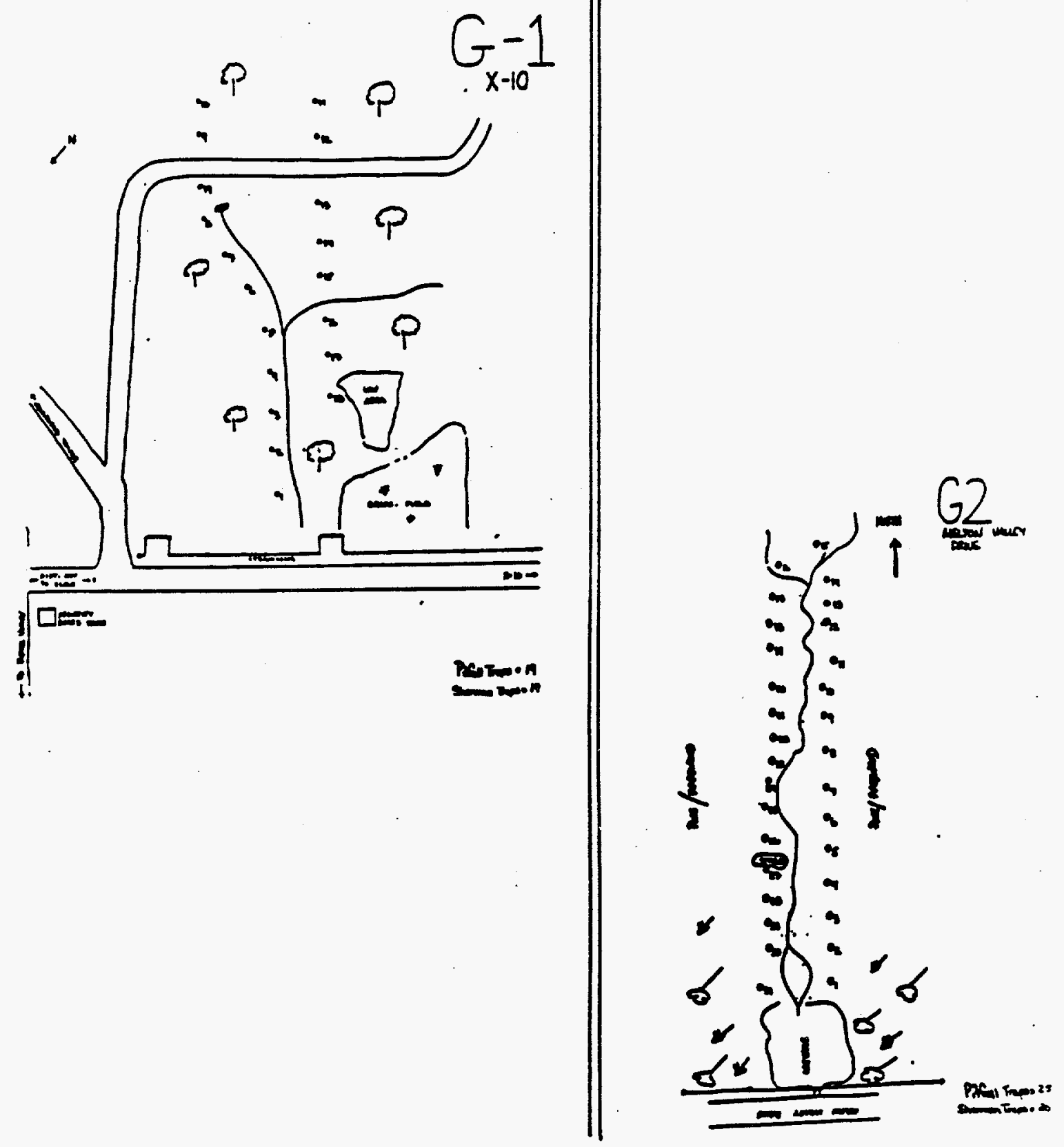




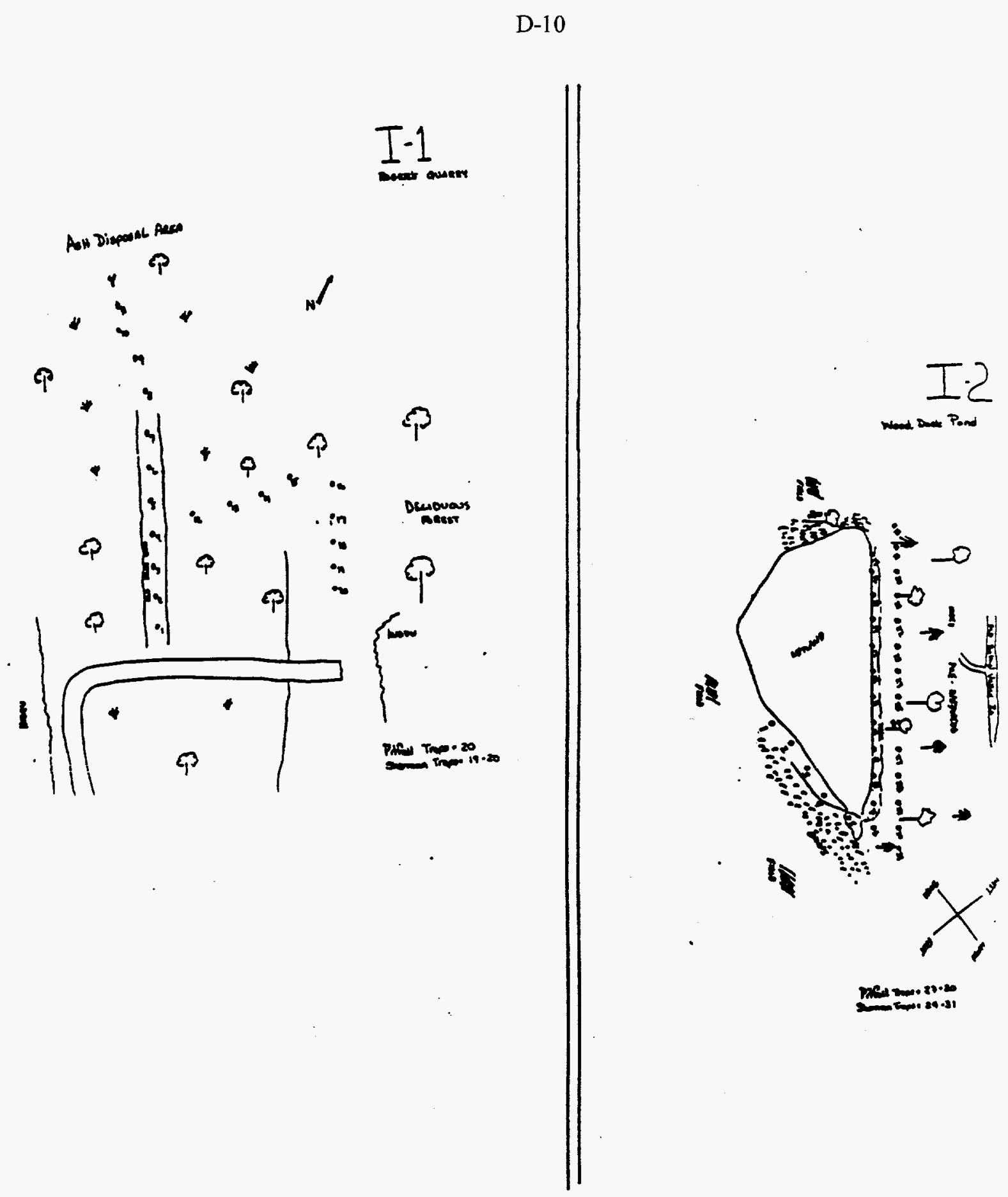


D-11

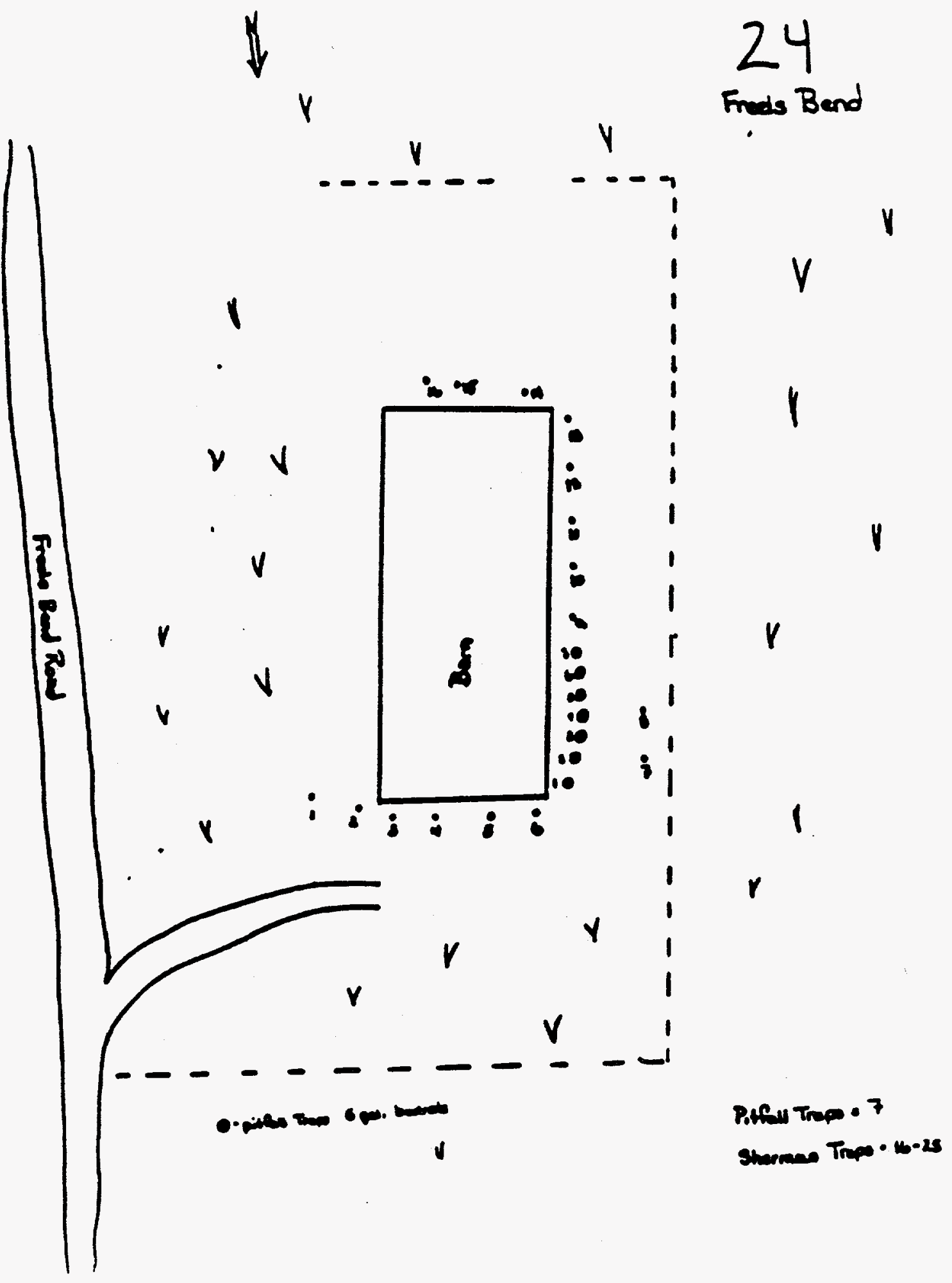



Appendix E

CAVE LOCATIONS ON THE ORR 


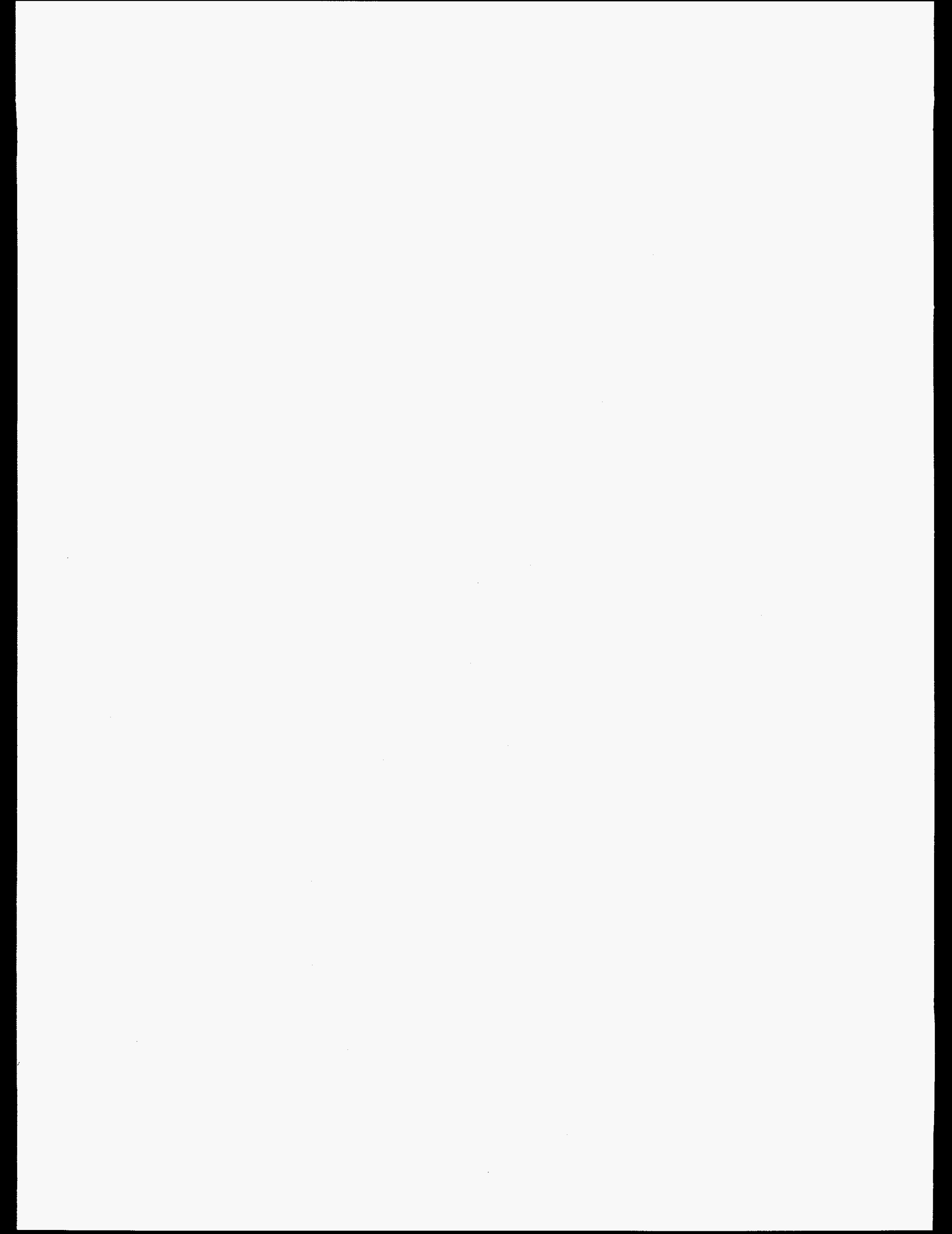




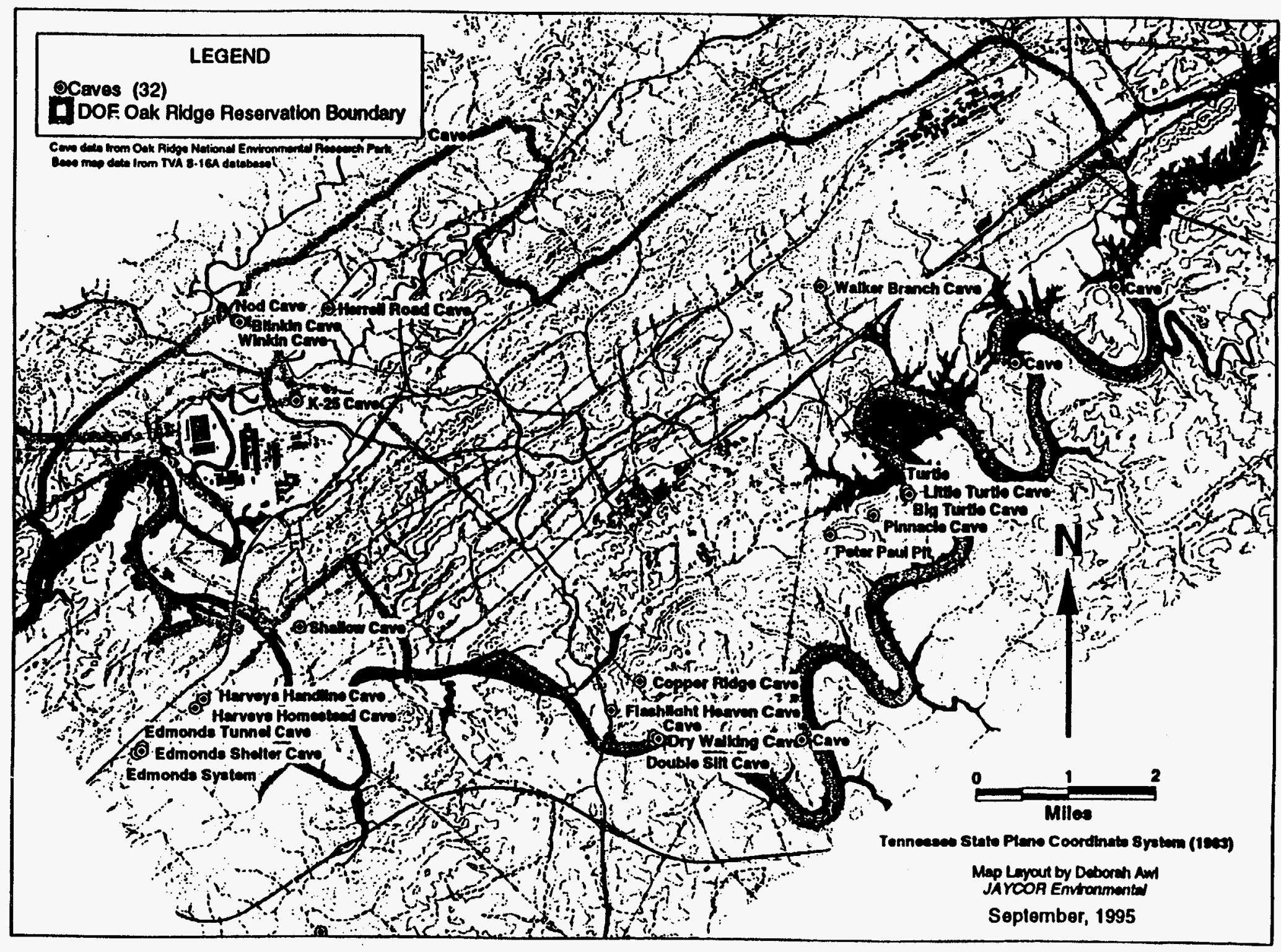




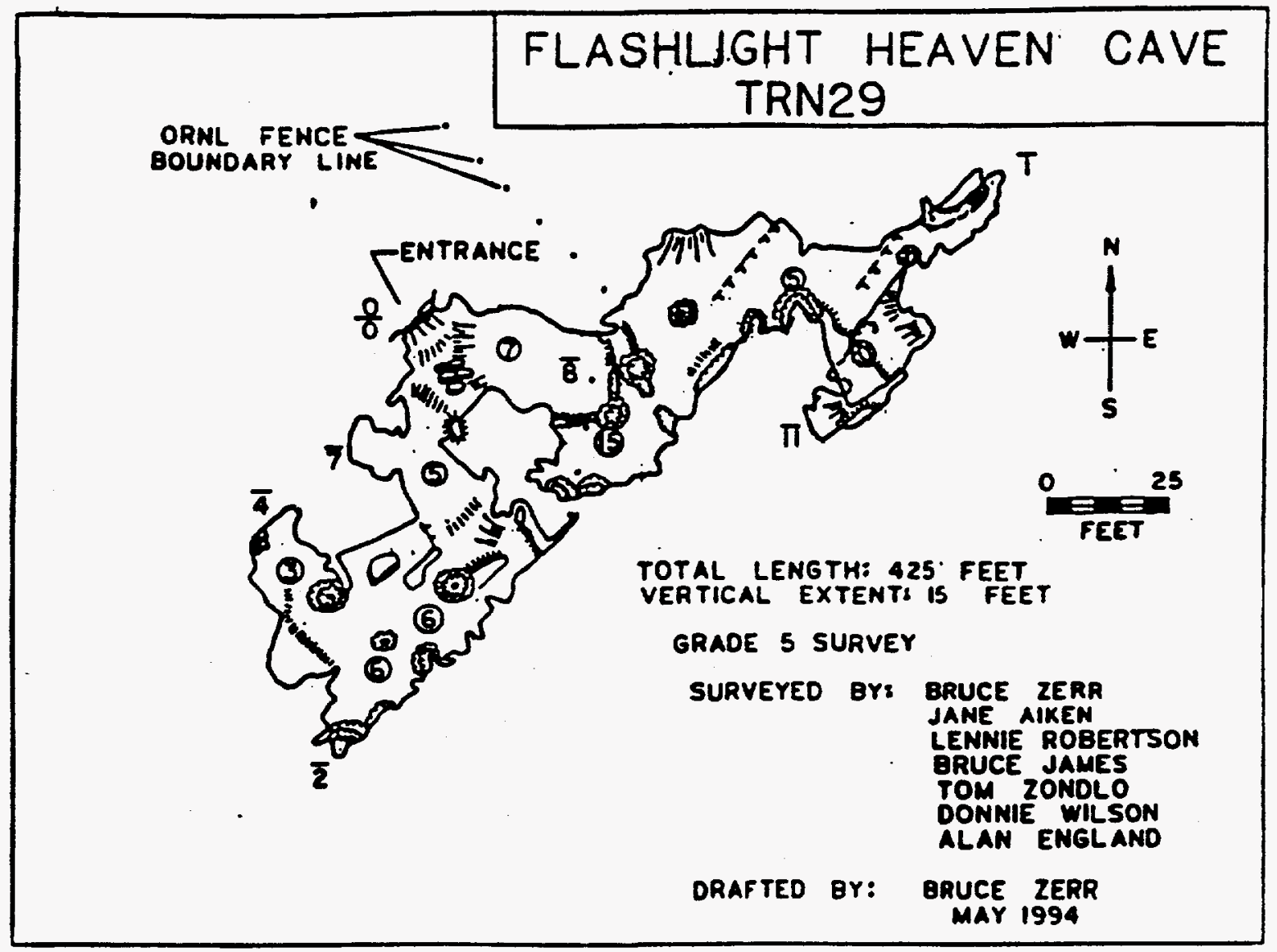


Appendix F

MAPS OF SURVEYED CAVES ON THE ORR, FEBRUARY-SEPTEMBER 1995 

COPPER RIDGE CAVE crumow aw rape suaver mari)

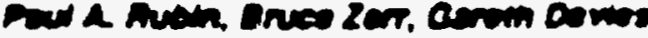
Low Dow Casinion $127 \mathrm{cs}$
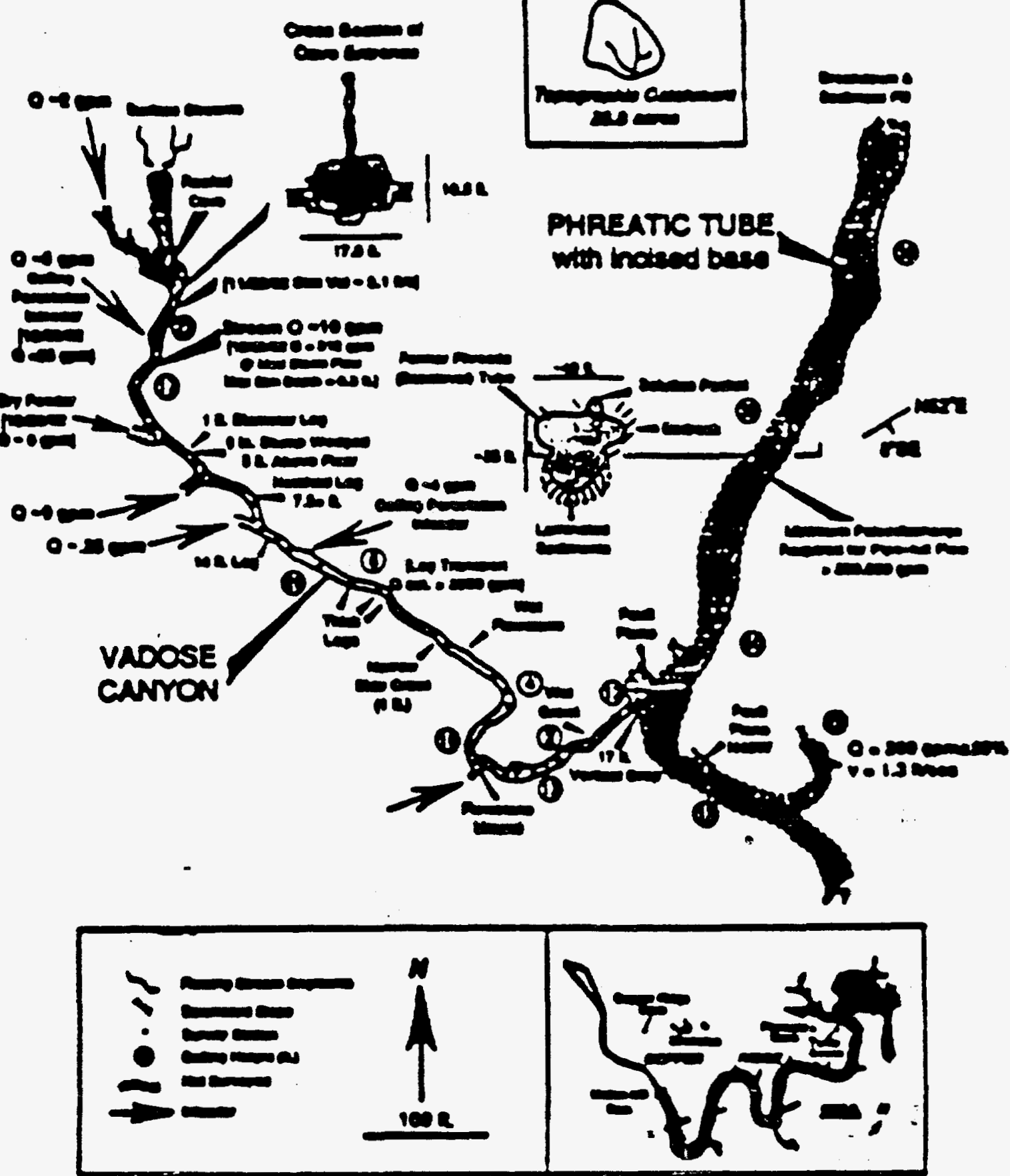
Pumaces CAVE

encermerm

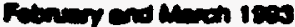

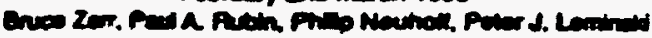

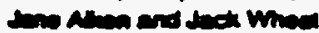

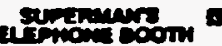

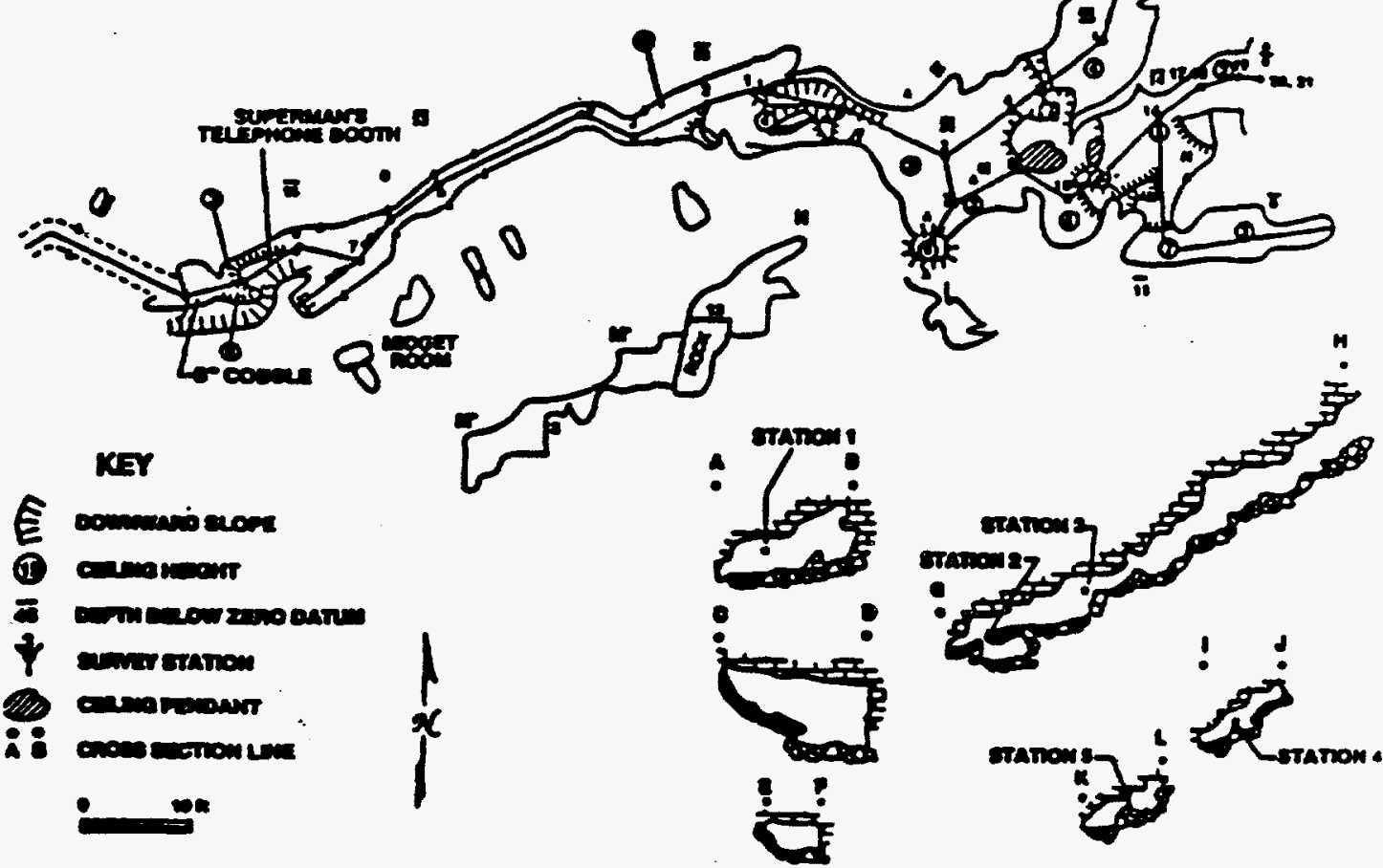

$8^{0}$

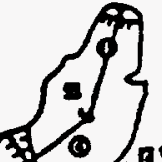

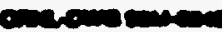

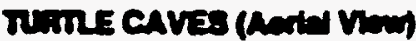

cones

Fincers ins

Dres $20 \pi$

puna new

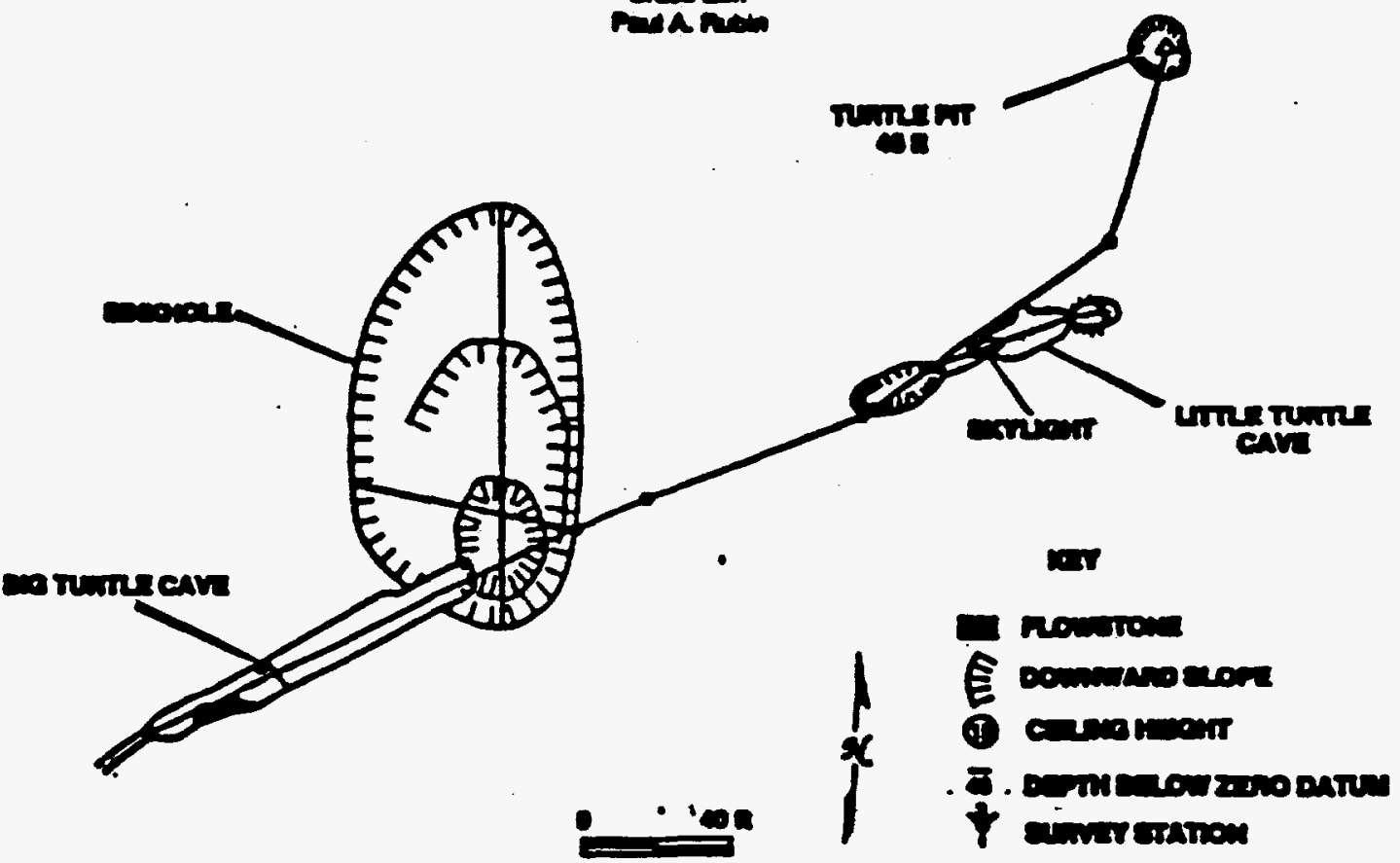


F-5

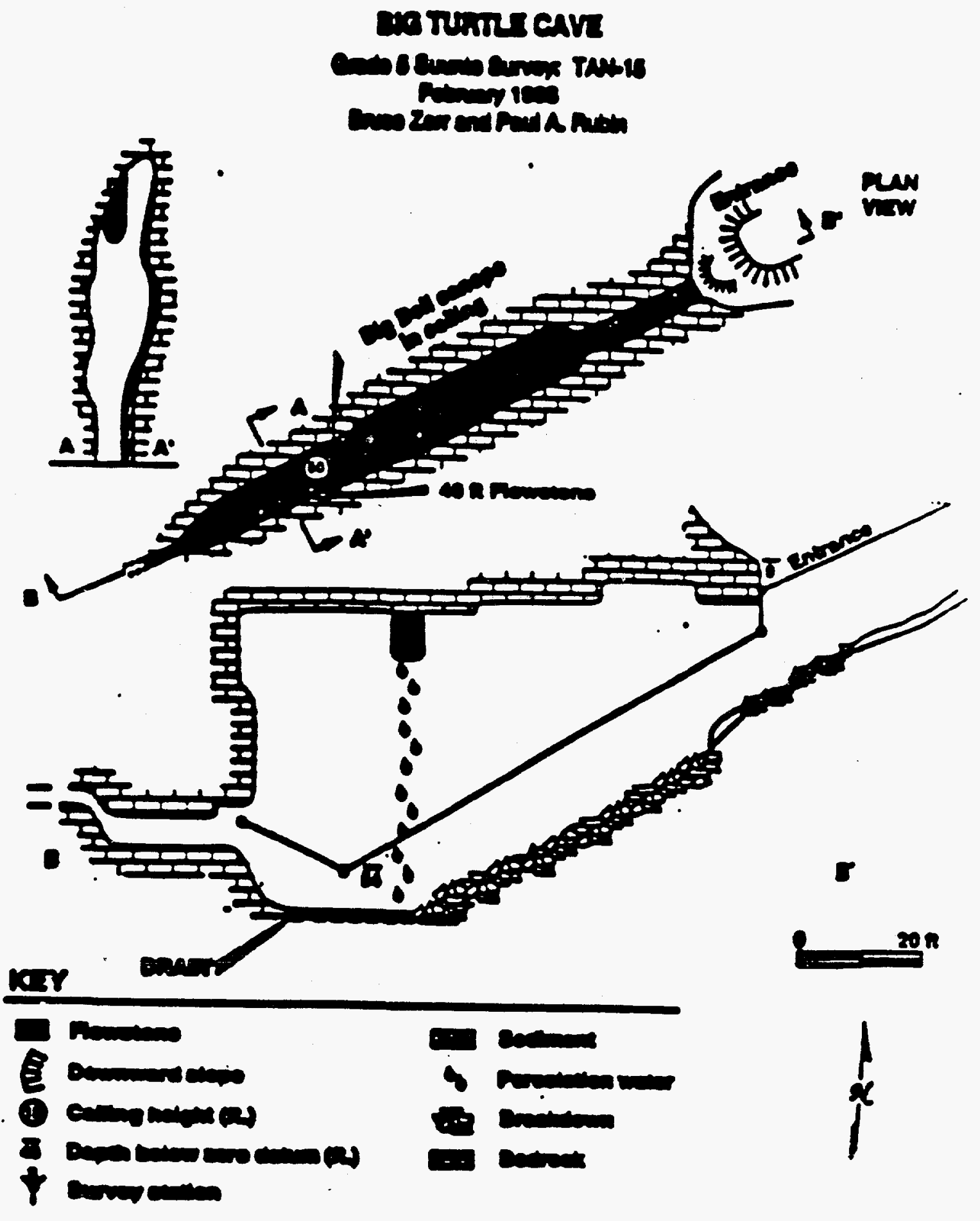



Appendix G

PROTOCOL FOR HABITAT SAMPLING 


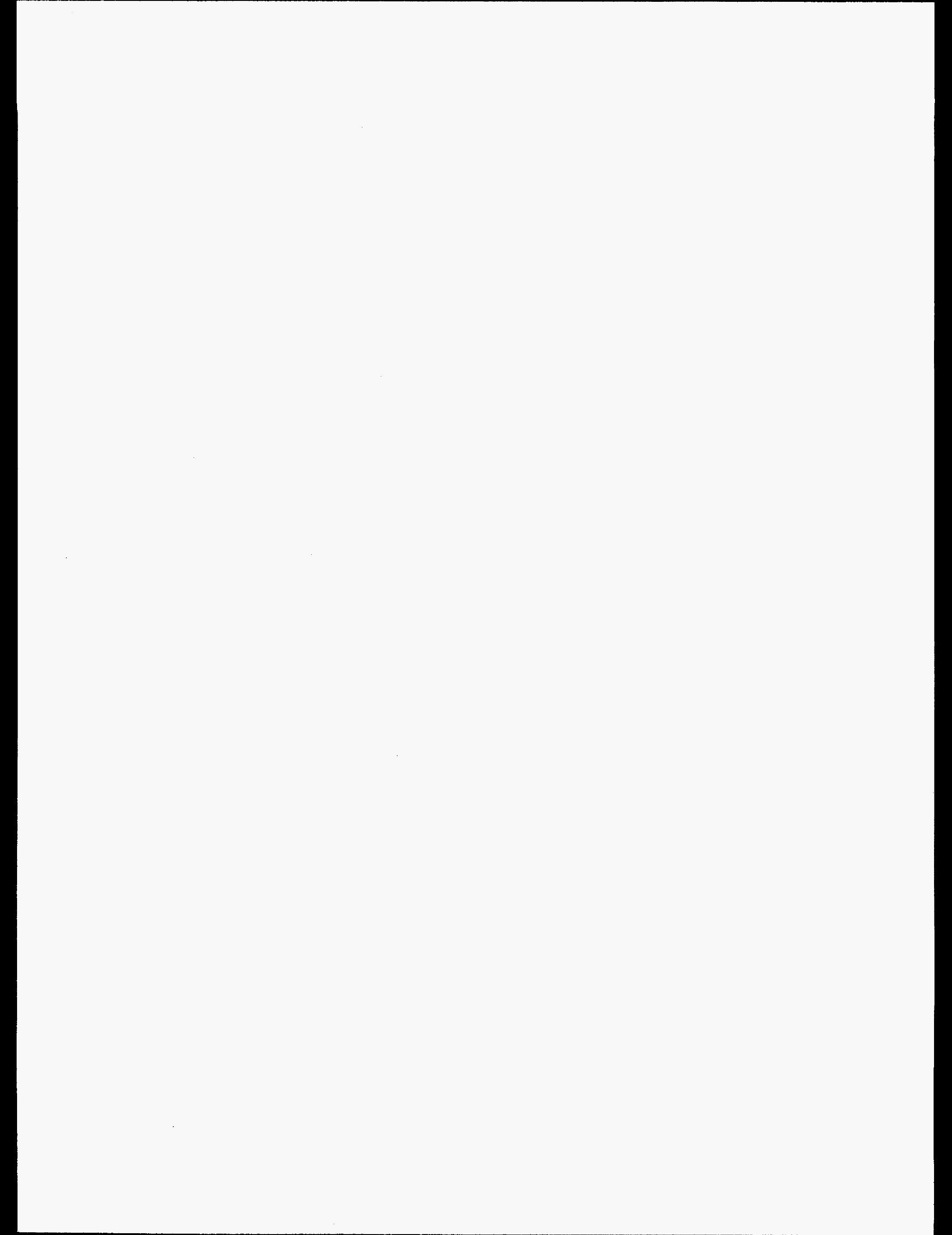


Site Name: The name and/or code assigned to the site.

Map: Any maps attached (e.g., S-16A, pitfall maps) should be noted.

Location: Directions to the location of the site. Include nearby roads, cemeteries, buildings, streams, power or gas lines, etc.

Latitude and Longitude: The coordinates of the site taken by the GPS.

Cover Type: The dominant cover type of the site (e.g., oak/hickory, pine/hardwood, pine, cedar, old field, etc.).

Basal Area: Measured in $\mathrm{m}^{2} / \mathrm{ha}$. Estimate the cross-sectional area of a tree at breast height by using a curz-all. The location for this measurement should be near the center of the site.

Litter Depth: The depth of the organic matter recorded in centimeters. Use a stick to measure depth, then measure the stick on a tape measure. The measurement should be taken at four random locations on the site, then averaged.

Average DBH (diameter at breast height): The diameter of at least four trees should be measured at breast height $(4.5 \mathrm{ft}$.). The trees should be representative of the site. Using a diameter tape, the result should be expressed in centimeters.

Dominant Plants: Record dominant plant species in each of the ground, understory, and canopy layers. Five to ten species should be listed in each category. Estimate vegetation height in meters in each of the stages.

General description: A subjective description of the presence of log debris, cavities, rock outcrops, bare ground, canopy gaps, soil disturbance, hard or soft edge, location of a natural area, etc.

General Topography: Record land features, general size of the area surveyed, presence of water, springs, slope of the site, aspect, etc.

Number of Traps: The number of Sherman traps used at the site should be recorded.

Number of Pitfalls: The number of functional pitfalls placed a the site should be recorded. 
Appendix H

DATA SHEETS USED FOR 1995 


\section{HABITAT DESCRIPTION}

Site Name:

Map:

Location:

Latitude:

Longitude:

Cover type:

Basal Area: $\left(\mathrm{m}^{2} / \mathrm{ha}\right.$

Litter Depth (cm):

Average dbh $(\mathrm{cm})$

Dominant plants and estimated height of each stage:

Ground: height $(\mathrm{m})$

Understory: height $(\mathrm{m})$

Canopy:

$$
\text { height (m): }
$$

General Description: (log debris, cavities, rock outcrops, bare ground, canopy gaps, soil, disturbance, edge, natural area)

General Topography: (slope, aspect, water, land features, size of area)

Number of traps

Number of pitfalls: 
Date:

TIme:

Sherman traps out: \# D18turbed: Iotal trap aighta:

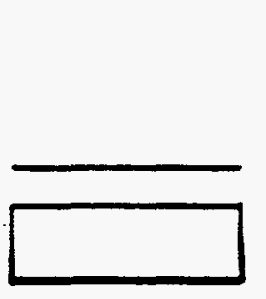

81te:

P1tfall traps out:

* 1noperable:

Total p1tealia:

\begin{tabular}{|c|c|c|c|c|}
\hline SPBCIES & Trap & Pitfall \# & Mark \# & Recapt \\
\hline 1 & & & $\cdot$ & \\
\hline 2 & & & & \\
\hline 3 & & & & \\
\hline 4 & & & $\cdot$ & \\
\hline 3 & & & & \\
\hline 6 & & & & \\
\hline 7 & & & & \\
\hline 8 & & & & \\
\hline 9 & & & & \\
\hline 10 & & & & \\
\hline 11 & & & & \\
\hline 12 & & & & \\
\hline 13 & & & & \\
\hline 14 & & & & \\
\hline 15 & & & & \\
\hline 26 & & & & \\
\hline 17 & & & & \\
\hline 18 & & & & \\
\hline 29 & & & & \\
\hline 20 & & & & \\
\hline
\end{tabular}

Commenes:

Recorded by:

w1tressed by:
Date:

Date : 
CAVING DATA SHEEI

Dace:

Cave Temp. (C) :

Inelow/Outelow Cave:
Cave Name:

Water Temp. (C) :

\begin{tabular}{|c|c|c|c|c|}
\hline Species & $\begin{array}{l}\text { Total } \\
\text { Length } \\
(\mathrm{cm})\end{array}$ & $\begin{array}{l}\text { Snout-Ant. } \\
\text { Vent Length } \\
\text { (cm) }\end{array}$ & $\begin{array}{l}\text { Srout - Post } \\
\text { Vent Length } \\
\text { (cm) }\end{array}$ & $\begin{array}{c}\text { Total } \\
\text { Individuals }\end{array}$ \\
\hline \multicolumn{5}{|l|}{1} \\
\hline \multicolumn{5}{|l|}{2} \\
\hline \multicolumn{5}{|l|}{3} \\
\hline \multicolumn{5}{|l|}{4} \\
\hline \multicolumn{5}{|l|}{5} \\
\hline \multicolumn{5}{|l|}{6} \\
\hline \multicolumn{5}{|l|}{7} \\
\hline \multicolumn{5}{|l|}{8} \\
\hline \multicolumn{5}{|l|}{9} \\
\hline \multicolumn{5}{|l|}{10} \\
\hline \multicolumn{5}{|l|}{11} \\
\hline \multicolumn{5}{|l|}{12} \\
\hline \multicolumn{5}{|l|}{13} \\
\hline \multicolumn{5}{|l|}{24} \\
\hline 15 & & & & \\
\hline
\end{tabular}

Total No. Bate!

Comment8:

Recorded By:

witnesed By:
Dare :

Dace: 
Deta sheet: pond survey

Date:

Time :

Fog :

Cloudcover (t)
Site \#/Pond\#:

Field Temp. (F): wind: Open/Forest

Water Term. (F): Precip. Seine/Other:

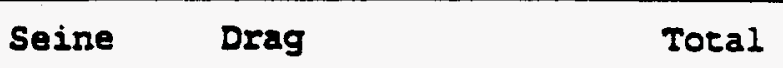

Species Drag \# Width Length Sex Individuals

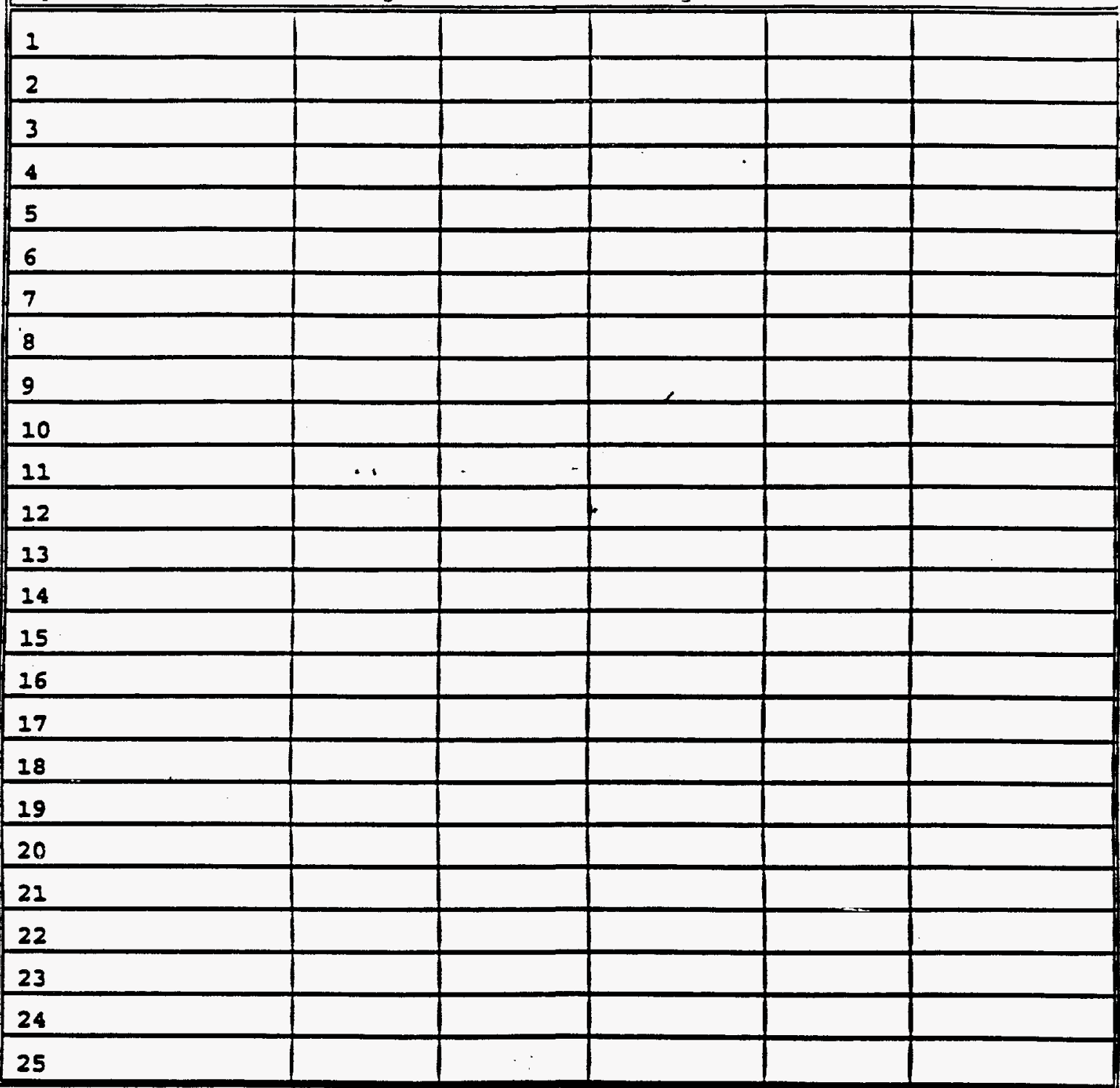

Commencs :

Recorded By:

Witnessed BV:

Date :

Date: 
Appendix I

\section{LISTED SPECIES OBSERVED} ON THE ORR DURING 1994 



\begin{tabular}{lll}
\hline \multicolumn{1}{c}{ Species } & \multicolumn{1}{c}{ Status } & \multicolumn{1}{c}{ Date Found } \\
\hline Double-crested cormorant & In need of management (state) & June 1994 \\
Osprey & Threatened (state) & June 1994 \\
Bald eagle & Threatened (federal) & August 1994 \\
Cooper's hawk & In need of management (state) & August 1994 \\
Northern harrier & In need of management (state) & September 1994 \\
Great egret & In need of management (state) & June 1994 \\
\hline
\end{tabular}


Appendix $\mathbf{J}$

SPECIES OBSERVED ON THE ORR

DURING 1994 BUT SUBSEQUENTLY DELISTED 


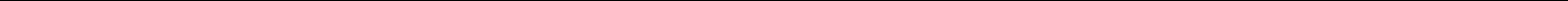


J-3

\begin{tabular}{lll}
\hline \multicolumn{1}{c}{ Species } & \multicolumn{1}{c}{ Previous Status } & Date Found \\
\hline Red-headed woodpecker & In need of management & June 1994 \\
Black-crowned night heron & In need of management & June 1994 \\
Red-shouldered hawk & In need of management & May 1994 \\
Black vulture & In need of management & Common \\
Cumberland slider & In need of management & Common \\
\hline
\end{tabular}




\section{Appendix K}

\section{INDIVIDUALS WHO HAVE IDENTIFIED}

T\&E BIRD SPECIES ON THE ORR 

Brewer, Robert

Bymiller, Robert

Carricco, Brian

Combs, Melissa

Evans, Jim. W.

Gehl, Ronald

Herd, Dick

Kroodsma, Roger

Lane, Jim

McCracken, Kitty

Mitchell, Jason M.

O'Neil, Brenda

Osburn, Keith

Rathmell, Lon

Roy, Kelly W.

Ryon, Mike

Schilling, Elizabeth

Vail, Elizabeth R.

Webb, J. Warren

Wilkerson, Stanley

Wojtowicz, John
Master's student, University of Tennessee (U.T.)

Falconer, Lockheed Martin Energy Systems, Inc. (LMES)

Fisheries biologist, Jaycor Corporation

Summer intern, U.T.-Chattanooga

Wildlife manager, TWRA

Summer intern, Purdue University

Wildlife biologist, TWRA

Ornithologist, LMES

Wildlife biologist, U.T.

Aquatic ecologist, LMES

Wildlife biologist, Jaycor Corporation

Wildlife biologist, LMES

Summer intern, LMES

Wildlife biologist, U.T.

Fisheries biologist, LMES

Fisheries biologist, LMES

Fisheries biologist, LMES

Environmental biologist, Jaycor Corporation

Terrestrial ecologist, LMES

Entomologist, Jaycor Corporation

Entomologist, Jaycor Corporation 
ES/ER/TM-174

\section{DISTRIBUTION}

1. T. L. Ashwood

2. L. V. Asplund

3. H. L. Boston

4. V. J. Brumstock

5. J. S. Colley

6. K. W. Cook

7. R. B. Cook

8. D. G. Cope

9. R. C. Durfee

10. J. W. Evans

11. P. L. Goddard

12. R. L. Graham

13. C. S. Haase

14. P. A. Hamlett

15. D. D. Herr

16. R. K. Holmes

\author{
17. B. L. Kimmel \\ 18-19. A. L. King (2) \\ 20. J. R. Lyons \\ 21. J. C. Massey \\ 22-24. D. M. Matteo (3) \\ 25. M. E. Musolf \\ 26. P. L. Osborne \\ 27-28. P. T. Owen (2) \\ 29. P. D. Parr \\ 30-32. A. S. Quist (3) \\ 33. C. T. Rightmire \\ 34. K. M. Steele \\ 35. T. D. Taylor \\ 36-37. J. W. Webb (2) \\ 38. D. C. White \\ 39. R. K. White
}

40. Central Research Library

41. ER Central Doc. Mgmt. Center - RC

42-43. ER Central Doc. Mgmt. Center (2)

44. D. M. Carden, U.S. Department of Energy-Oak Ridge Operations Office, P.O. Box 2001, Oak Ridge, TN 37831-8600

45. Office of Assistant Manager for Energy Research and Development, U.S. Department of Energy-Oak Ridge Operations Office, P.O. Box 2001, Oak Ridge, TN 37831-8600

46. S. P. Riddle, U.S. Department of Energy-Oak Ridge Operations Office, P.O. Box 2001, Oak Ridge, TN 37831-8600

47. D. J. Awl, Jaycor Corporation, 60 Scarboro Road, Suite D, Oak Ridge, TN 37831

48. J. M. Mitchell, 60 Scarboro Road, Suite D, Oak Ridge, TN 37831

49. E. R. Vail, 60 Scarboro Road, Suite D, Oak Ridge, TN 37831 